\title{
Political determinants of efforts to protect victims of human trafficking
}

\author{
Johanna Schönhöfer ${ }^{1}$
}

Published online: 27 October 2016

C The Author(s) 2016. This article is published with open access at Springerlink.com

\begin{abstract}
In focusing on characteristics of national cabinets and parliaments, this paper seeks to understand domestic factors that are conducive to the enforcement of policies which protect victims of human trafficking in 33 democratic member countries of the European Union (EU) and the Organisation for Economic Co-Operation and Development (OECD). It argues for the need to consider the role of policymakers when trying to understand what drives the implementation and enforcement of international treaties that combat organized crime, such as the United Nations Protocol to Prevent, Suppress and Punish Trafficking in Persons, Especially Women and Children, in national policies. In so doing, the paper applies theoretical arguments of comparative politics to criminology. Multivariate analyses show that the share of female parliamentarians and the proportion of left wing and social democratic parties in cabinet are significantly and positively associated with stronger efforts to protect victims of human trafficking. Future research should expand the insights of this analysis through case studies on parliamentary behaviour, legislative proposals, and votes related to human trafficking.
\end{abstract}

Keywords Human trafficking - Victim protection - Compliance - Anti-trafficking policies $\cdot$ UN anti-trafficking protocol $\cdot$ Political science

\section{Introduction}

Human trafficking generates billions in profit at the expense of thousands of victims each year $[1,2: 75 ; 3]$. This makes understanding the dynamics leading to measures and policies designed to protect victims of trafficking a critical task. Human trafficking is defined as "[...] the recruitment, transportation, transfer, harbouring or receipt of

Johanna Schönhöfer

1wjas@leeds.ac.uk

1 School of Law, Centre for Criminal Justice Studies, University of Leeds, Moorland Road,

Leeds LS2 9JT, UK 
persons, by means of the threat or use of force or other forms of coercion, of abduction, of fraud, of deception, of the abuse of power or of a position of vulnerability or of the giving or receiving of payments or benefits to achieve the consent of a person having control over another person, for the purpose of exploitation" ([4]: Art. 3(a)). The trade in human beings affects almost all countries in the world, albeit in a variety of ways [5]. In cases where victims are trafficked across borders countries can be origin, destination, or a site of transit for victims of human trafficking. Origin countries are states where victims get recruited and trafficked away from. Destination countries are states in which the actual exploitation for labour, involuntary sexual services, and other forms of slavery takes place. Transit countries are states which are passed through by victims of trafficking during their transport from origin to destination countries. These categories are not mutually exclusive, as countries can be origin, destination and sites of transit for human trafficking simultaneously. Although human trafficking is conventionally conceived as international crime, domestic trafficking constitutes a significant share of all detected trafficking cases around the world $[6,7]$. In the context of domestic trafficking recruitment of victims, transport, and exploitation takes place within the same country.

Currently, one of the most important global instrument to combat human trafficking is the UN Protocol to Prevent, Suppress, and Punish Trafficking in Persons, Especially Women and Children (also known as "UN Anti-Trafficking Protocol" or "Palermo Protocol"), which was adopted in 2000 and entered into force in 2003. It supplements the United Nations Convention Against Transnational and Organized Crime and divides counter trafficking efforts into three policy dimensions: prevention of further incidences of trafficking, prosecution of traffickers, and protection of victims. To date the UN Anti-Trafficking Protocol has been ratified by 169 countries, ${ }^{1}$ but since it lacks formal enforcement, monitoring, and sanction mechanisms, the levels of compliance vary considerably between states [8, 9].

This paper aims to examine compliance with articles concerning victim protection of the UN Anti-Trafficking Protocol. The paper focuses on the impact of domestic policymaking, and thus examines the characteristics of national cabinets and parliaments in a sample of 33 democratic member countries of the European Union (EU) or the Organization for Economic Co-Operation and Development (OECD). In so doing the study applies a political science framework to a problem that has hitherto been mainly cast in criminological terms. Being created under the auspice of the UN Crime Commission, the UN Anti-Trafficking Protocol was issued under a crime framework, which has lead to a particular emphasis on prosecution and prevention, while the articles concerning victim protection measures are formulated with a less binding character [10]. Victim protection and rehabilitation however are pivotal pillars in the fight against human trafficking which aims to have long-lasting effects. However, victim protection is a 'demanding' policy dimension to comply with. The UN Anti-Trafficking Protocol instructs states to grant amnesty to trafficking victims, which often requires changes in a state's criminal and immigration laws [4]. Likewise, provision of shelter, legal and medical assistance as well as authorizing residency permits for trafficking victims are important pillars for protection and empowerment, but they are also expensive. The combination of high costs associated with victim protection measures on the one hand

\footnotetext{
${ }^{1}$ See https://treaties.un.org/Pages/ViewDetails.aspx?src=TREATY\&mtdsg_no=XVIII-12-a\&chapter= 18\&lang=en (accessed 7 June 2016).
} 
and wide discretion conceded to states in regards to compliance with this dimension owing to the crime framework of the Protocol on the other hand results in high incentives for states to avoid additional cost and little incentives to comply. This provides an interesting context in which to study the role of internal characteristics of states which may be conducive to the enforcement of policies to protect victims of human trafficking as stipulated in the UN Anti-Trafficking Protocol.

Previous research on the adaptation and enforcement of anti-trafficking policies has predominantly drawn on theories of international relations: states are conceptualized as unitary, coherent and rational actors whose decisions depend on the structure of the international system, irrespective of their internal, political composition [9, 11-13]. Hence, counter trafficking efforts are often seen as a product of what happens in the international system, rather than being brought about by processes within states themselves such as advocacy and political representation $[14,15]$. An assessment of the role of characteristics of domestic political factors which are associated with comprehensive victim protection efforts however is important since eventually it is the responsibility of the ratifying nation state to implement and enforce the policies proposed in the UN AntiTrafficking Protocol. Hence, understanding what drives the enforcement of victim protection policies warrants a closer examination of domestic legislators, which are responsible for policymaking. While studies have repeatedly established a positive link between anti-trafficking efforts and the representation of women in national parliaments as well as respect for the rights of women in society $[8,9,12,14,16]$, there are currently no studies which have analysed characteristics of parliaments and governments beyond the representation of women in political institutions. Consequently we know little about how the ideological composition of governments and parliaments shape victim protection efforts of nation states and whether the positive association between the percentage of female parliamentarians and compliance with anti-trafficking treaties remains significant when other government characteristics are controlled for. Anti-trafficking campaigns often work with strongly gendered stereotypes of female victims trafficked by male perpetrators $[17,18]$. The depiction of women as the central group among victims of human trafficking makes counter- trafficking efforts in general and the protection of victims in particular a central issue for feminist debate [19: 319; 20]. Hence, female politicians might take a greater interest in advocating policies to protect and empower trafficking victims. The debate of human trafficking however goes beyond feminism in its scope, making it relevant to advocates of human rights, too. Therefore additional ideological characteristics of national governments should be relevant for compliance with victim protection as stipulated in the UN Anti-Trafficking Protocol. Since trafficking victims are among the most deprived population groups, cabinets and parliaments committed to social justice and the inclusion of underprivileged minorities might be more inclined to adopt the UN Anti-Trafficking Protocol's proposal for victim protection.

This article first provides a brief description of the UN Anti-Trafficking Protocol. A review of literature establishing characteristics of national governments and parliaments that might affect a state's enforcement of victim protection policies follows, from which four hypotheses about the effects of ideological as well as gender composition of national cabinets and parliaments on efforts to protect victims of human trafficking are extracted. These are tested in a sample of 33 democracies between 2000 and 2011 using ordered logit regression. The last section concludes with implications for future research and political reality. 


\section{The UN Anti-Trafficking Protocol}

The fight against human trafficking looks back on 100 years of transnational legal effort. The 1926 Slavery Convention is the first of many international conventions against the trade of human beings implemented during the twentieth century. In the course of increased awareness for transnational crime the OECD and EU member countries made the eradication of human trafficking a priority issue [21, 22: 101-103]. Simultaneously, Nongovernmental Organisations (NGOs) campaigned for a global instrument to facilitate the fight against the trade in human beings [12: 304; 23: 422]. As a result, in 1999 a UN ad-hoc committee supervised by the UN Crime Commission met to develop the United Nations Convention Against Transnational Organized Crime and its supplementary protocols. Adopted in 2000, the Protocol to Prevent, Suppress, and Punish Trafficking in Persons, Especially Women and Children supplementing this UN Convention has become a legal standard for global efforts to curb human trafficking [23: 422; 24: 82; 22: 104]. In order to comply with the three policy dimensions of prevention, prosecution, and protection, ratifying states must implement a series of measures into their domestic policies. Yet, the Protocol imposes no direct sanctions for non-compliance upon ratifying countries [25: 121].

To prevent trafficking, states need to exchange information and initiate research and campaigns to raise awareness for the trade in persons. Furthermore, the Protocol requests the eradication of factors contributing to the vulnerability of populations for trafficking and exploitation such as poverty, unequal opportunities, and underdevelopment ([4]: Art. 9). The articles concerned with criminalization urge states to establish the trade in human beings as a criminal offense in their domestic legislation to enable the prosecution of traffickers and their accomplices ([4]: Art. 5). Protection of victims consists of confidential court proceedings, the provision of legal counselling, housing, medical care, and compensations, as well as employment opportunities and education ([4]: Art. 6). Furthermore, Art. 7 suggests the alteration of domestic legal frameworks in order to provide victims with the opportunity to (temporarily) reside in the country where the trafficking incident was detected. Article 8 summons the victims' states of origin to facilitate their voluntary and safe repatriation by re-issuing lost or stolen passports.

The strategies of protection, prevention and prosecution differ in cost and effort, with victim protection prescribing some of the most expensive measures to comply with. Moreover, the three policy dimensions are not equally binding. Since the UN AntiTrafficking Protocol was issued by a law-enforcement body - the UN Crime Commission - it is written with a "crime-fighting frame" [10: 324] which emphasises punitive above protective measures [26: 67]. Articles concerned with prevention and prosecution are formulated in imperative, whereas the Protocol's instructions for victim protection are attributed with extenuations like "in appropriate cases", "state parties shall consider", or "to the extent possible under domestic law" ([4]: Art. 6-8; [24]: 83). The discretion conceded to ratifying countries in regards to the protection of trafficking victims makes compliance with this dimension of the UN Anti-Trafficking Protocol a particularly interesting subject to study, especially with a focus on the role of domestic politics. Incentives for compliance with victim protection measures as stipulated in the UN Anti-Trafficking Protocol are little: on the one hand the Protocol's guidelines in regards to victim protection are not binding. On the other hand victim protection entails some of the most costly measures. Assuming that states are rational actors we should 
therefore be able to identify domestic concerns and interests that foster compliance with guidelines, which are not externally imposed. The analysis of states' victim protection efforts in the context of the UN Anti-Trafficking Protocol instead of more binding documents like the 2011 EU Directive on Combating Trafficking in Human Beings and Protecting its Victims or the 2005 Council of Europe Convention on Action against Trafficking in Human Beings provides a promising approach to identify domestic factors driving protection efforts. This offers a necessary internal perspective to supplement existing research on anti-trafficking efforts with its focus on international relations.

\section{Explaining anti-trafficking efforts}

Different levels of compliance with the UN Anti-Trafficking Protocol have attracted scholars' attention $[8,9,15,16,26-30]$. This research has identified a set of factors that drive states' efforts to prosecute and prevent human trafficking as well as to protect its victims. Compliance with the UN Anti-Trafficking Protocol entails international consequences. On the one hand a country's procedures against human trafficking might displace the problem to adjacent states [9, 11: 251]. On the other hand successful combat of trafficking in destination- and transit states depends on countermeasures in origin states accountable for most of the former's trafficking inflow [31: 5]. Therefore, counter-trafficking efforts are often studied with a theoretical framework based on international relations.

International relations theory and research perceives states as sovereign, coherent, and rational entities, which engage with and influence each other in the "international system" $[32,33]$. The international system is characterized by power differentials, as some states are more influential than others. International relations suggest two main reasons for states to comply with international treaties lacking formal enforcement and sanction mechanisms like the UN Anti-Trafficking Protocol: they are either coerced into compliance by other states [32-34], or compliance is a strategic choice of states in order to raise their reputation and signal credible commitments [35-38].

Coerced compliance may occur because destination countries have an interest in origin and transit countries tackling the trade in human beings, so that fewer trafficking flows will affect the receiving states [39]. To this end, powerful destination states can impose unilateral sanctions on origin countries accountable for most of their trafficking inflows [40]. Analyses have shown that states which are susceptible to international pressure due to a poor ranking in the annual Trafficking in Persons (TIP) Reports issued by the US Department of State [41] or financial loans from the USA are subsequently more likely to implement and enforce anti-trafficking policies [8, 13, 14: 23, 28; 42]. Strategic compliance may occur when countries invest in anti-trafficking policies as a means of demonstrating their devotion to human rights matters in order to reach other goals, like entering trade partnerships or membership in prestigious international organizations. For that matter, seeking membership in or being member of organizations such as the European Union (EU) or the North Atlantic Treaty Organization (NATO) has proven to exert significant positive influence on implementation and enforcement of anti-trafficking laws in post-communist countries [12].

From an international relations perspective a third reason for compliance with global treaties such as the UN Anti-Trafficking Protocol might be the existence of regional 
treaties and anti-trafficking directives. Especially in Europe a number of binding international documents and clarifications of states' responsibilities in regards to human trafficking with a particular focus on the protection of victims have emerged after 2000, while in other regions the UN Trafficking Protocol is still the dominant tool to combat trafficking. The Council of Europe Convention on Action against Trafficking in Human Beings (Warsaw Convention), which was passed in 2005 and came into force in 2008, stipulates that the identification and protection of victims are "paramount objectives" [21: 7] in the fight against human trafficking. Besides this focus on victims' rights the Warsaw Convention is accompanied by formal monitoring mechanisms through the Group of Experts on Action Against Trafficking (GRETA) which further increases liability for states. In 2010 the European Court of Human Rights (ECtHR) clarified in its judgement on the case Rantsev vs. Cyprus and Russia (2010) 51 EHHR 1 that although the protection of victims of human trafficking is not explicitly mentioned it is covered by Article 4 of the European Convention of Human Rights (ECHR). The judgement spells out that in face of existing European legislation it is compelling for authorities in all Council of Europe member states to proactively investigate in circumstances that potentially involve human trafficking, and to provide for the safety of potential trafficking victims. The judgement further broadens the prosecutive approach to human trafficking by emphasising requirements in regards to prevention of trafficking and protection of its victims. Lastly, in 2011, the European Union adopted the Directive on Combating Trafficking in Human Beings and Protecting its Victims, which further enhances the legal rights of trafficking victims. Amongst others the EU Directive urges states to tailor protection measures to the gender as well as the trafficking purpose of victims. Through their binding character as well as their promotion of victim-centered approaches in combatting human trafficking all three regional documents are likely to influence state compliance with the global UN Anti-Trafficking Protocol, especially in regards to the dimension of victim protection.

Research also indicates that states' internal attributes and processes can contribute to the enforcement of anti-trafficking efforts and implementation of measures to protect trafficking victims. In an analysis of all countries included in the 2009 US Department of State's Trafficking in Persons Report, Wooditch [15] finds that a high status of women in society increases trafficking related prosecutions. Bartilow [14] discovered further evidence for the positive association between women's equal rights and states' counter-trafficking enforcement. In addition, Bartilow's study shows a positive effect of gender representation in government and legislative chambers on the enforcement of anti-trafficking legislation, which is corroborated by later research [12: 316]. Freedom of the press is another factor conducive to compliance with the UN Anti-Trafficking Protocol [27], indicating the relevance of communication channels for interest groups. Besides Wooditch's [15] analysis, the above studies allow no statement on possible divergent effects on the enforcement of prevention, prosecution and protection policies, as they assess the overall extent of government action taken against human trafficking.

Those studies analysing compliance separated into the UN Anti Trafficking Protocol's three policy dimensions find that in correspondence with the emphasis of the Protocol many countries' efforts regarding prosecution and prevention are strong, whereas most governments score poorly on their efforts to protect victims $[8,9,16]$. This finding reflects the unbinding character of the Articles concerned with victim protection caused by the crime framework under which the UN Anti-Trafficking 
Protocol was issued with its focus on prosecution and prevention. Furthermore, high costs associated with victim protection policies can account for sub-standard achievements [8: 254]. In addition, states might prefer prosecution over protection because they fear generous treatment of victims might lead to increased illegal immigration [11]. Nevertheless, we find a number of states, which enforce comprehensive victim protection measures as part of their counter-trafficking efforts despite the high costs and the non-binding character of articles concerned with victim protection in the UN AntiTrafficking Protocol. They are often characterised by being of civil law origin [11] as well as the absence of corruption [8, 9, 30]. Likewise, governments in countries with Christian majorities on average carry out more comprehensive victim protection than countries where the majority is of Muslim faith, while however these differences are more pronounced in autocracies than in democracies [16: 18-20].

The above findings indicate the importance of structural opportunities to raise concerns and claims related to human trafficking, as well as the need for agents who are willing to implement these demands into policies and practice. However, research has not yet scrutinized which features of government and parliament beyond the share of female parliamentarians are associated with the provision and enforcement of comprehensive victim protection policies. This is surprising, as cabinet and parliament are core institutions of national policymaking. Which of their attributes might be conducive to the implementation of strong efforts to protect victims of human trafficking?

\section{Hypotheses}

Studies have identified a positive relation between the share of parliamentary seats held by women and endeavours to fight human trafficking in regards to prosecution but also concerning prevention and the protection of victims $[8,9,12,14,16]$. The percentage of female members in parliament measures so-called "descriptive representation" of women. Descriptive representation means that the descriptive characteristics of elected representatives reflect the demographic composition of the represented population [43]. This descriptive representation can lead to "substantive representation", which means that politicians purposely act on behalf of their counterparts in society who share the same descriptive characteristics [43, 44: 60-91]. The transition from descriptive to substantive representation is possible whenever an issue at stake invokes shared concerns rooted in a common ethnic, social- or gender-based background of representatives and the represented [45-48]. Substantive representation of female interests by female members of parliament is illustrated by the fact that the latter have been shown to be more likely to introduce and pass legislation that addresses women's concerns such as child support, equal pay, or criminalization of sexual assault and domestic violence [49-54]. Anti-trafficking campaigns often portray stark gendered stereotypes of female victims suppressed by male traffickers $[17,18,55]$. The UN Anti-Trafficking Protocol's full name itself contributes to this understanding through its suffix "especially women and children", which displays victim protection as a policy tool to preeminently empower women. I therefore expect:

H1: The higher the proportion of women in a country's federal parliament, the stronger are efforts to protect trafficking victims in this country. 
However, this positive association between women in parliament and comprehensive victim protection policies might change, once other characteristics of the legislative are taken into account. That is to say public policy output also depends on the preferences of the (majority) party in government [56, 57] as well as on parliament's support for their proposed policies [57-59]. Political parties differ in their ideological positions, and these ideological differences matter for a government's policy output [56, 60]. Social democratic parties in office consistently correspond to higher welfare expenditures and more generous social legislation [57, 61-63: 165, 171]. Hence, parties have clear preferences, which shape public policy proposals and -outputs of the parties in government. Policies to protect trafficking victims should appeal to left and social democratic parties, which reportedly endorse protection of vulnerable population as well as equal opportunities. Their aversion against social exclusion should shape government activity on human trafficking when they hold office:

H2: The proportion of left and other social democratic parties in a country's federal cabinet positively influences this country's compliance with victim protection.

Yet, in democratic political systems more actors than just the incumbent party are involved in policymaking to impose limits to the incumbent's scope of action [64].

The beneficial effect of the cabinet's ideology on a country's victim protection efforts is applicable to parliament as well [65, 66]. Victim protection policies contribute to social justice and special protection for underprivileged minorities. Therefore, victim protection efforts are expected to be more comprehensive where there is a favourable overall parliamentary attitude towards these two issues:

\section{H3.1: If a country's national parliament has a high proportion of positive attitude towards social justice, this country's victim protection efforts will be more pronounced.}

H3.2: If a country's national parliament has a high proportion of positive attitude towards the special protection of minorities, this country's victim protection efforts will be more pronounced.

In addition, left parties in cabinet and their parliamentary environment should have a combined effect on the existence and enforcement of victim protection policies. For the government's ideational preferences to show in policy output, the cabinet must overcome parliament votes against its policy propositions [57: 174]. No or little discrepancies between the cabinet's and the parliament's attitude towards social justice and the inclusion of underprivileged minorities implies that the protection-favouring party in government faces less resistance when parliament votes on their policy propositions especially if the share of cabinet seats held by left parties is small due to a coalition government. If government and the parliament agree, veto points can be passed more easily $[58,59]$. Hence, the effect of the share of left parties in cabinet on benevolent 
protection policies is conditional on the overall supportive attitudes towards social justice and the inclusion of minorities in parliament.

H4.1 The effect of left parties in cabinet will be more pronounced where the parliament favours social justice.

H4.2 The effect of left parties in cabinet will be more pronounced where the parliament favours the inclusion of underprivileged minorities.

\section{Data and methods}

\section{Case selection}

The above hypotheses are tested in a sample of 33 current democratic EU and/or OECD member countries over a period of 12 years (2000-2011). ${ }^{2}$ The countries were selected for three reasons. Firstly, the study focuses on internal government and parliament characteristics of states. Yet, the literature review has shown that international factors do play a role in explaining compliance with international treaties like the UN Anti-Trafficking Protocol. Building the sample around advanced industrial democracies levels differences in susceptibility to influence of international factors such as dependence on foreign aid or prospective membership in prestigious institutions. Nevertheless, differences in regards to economic pressure and affliction with human trafficking remain and will be controlled for in the analysis. This will allow for ascribing findings to the analysed internal factors.

Secondly, the countries in the sample are predominantly transit or destination countries of human trafficking. As such, they are the site of transport and exploitation for trafficking victims. Hence the study addresses the provision of protection measures for trafficking victims where the existence of the latter is most pressing, namely where victims find themselves most vulnerable, in a foreign environment and under the strain of exploitation.

Lastly, the eradication of human trafficking has been promoted as priority issue by EU and OECD member countries for the last 15 years [21, 22, 101-103]. Furthermore, the latter countries have played a key role in creating and promoting the UN AntiTrafficking Protocol. As a result, it is interesting to see whether this is "cheap talk" [29] or whether these states actively enforce their self-made international standards of the UN Anti-Trafficking Protocol to protect end empower victims of human trafficking within their national borders.

\section{Measures}

\section{Dependent variable}

The outcome of interest for this study is a country's enforcement of victim protection policies as stipulated in the UN Anti-Trafficking Protocol. This is assessed with the sub-index "protection" taken from the 3P Anti-Trafficking Index [8]. This index

\footnotetext{
${ }^{2}$ See Table 2 in the Appendix for a list of the sample countries.
} 
annually rates national government efforts to implement and enforce policies to protect trafficking victims on a five-point scale from the year 2000 onwards. A score of 1 indicates no efforts to protect trafficking victims, while 5 marks the best policy practice. The evaluation of policy practice and enforcement is based on the requirements formulated in the UN Anti-Trafficking Protocol. As such, no punishment for criminal offences committed by trafficking victims as a result of being trafficked (e.g. breaching immigration laws or engaging in prostitution in countries it is illegal), efforts to identify victims, provision for victims' physical, psychological and social recovery through housing, medical assistance, job training, and (temporal) residence permits are primary coding interests [8]. ${ }^{3}$ The sub-index "protection" gives an overall account of protection efforts suitable to answer the hypotheses of this study.

The information source for coding the sub-index "protection" are the annual Trafficking in Persons (TIP) Reports issued by the US Department of State and two additional reports published by the United Nations Office for Drugs and Crime [5, 7]. The TIP Reports contain narratives about the scope and form of human trafficking as well as government responses for more than 150 countries worldwide. They also include tier-rankings of countries based on their anti-trafficking efforts. The lack of transparency of these rankings and their use as a policy tool by the US government has been frequently criticised $[2,67: 239 ; 74 ; 68: 477 ; 41]$. Nevertheless, the country narratives in the TIP Reports are the only available source, which provides annual trafficking updates by simultaneously covering a broad range of countries [69: 10]. More recently the Group of Experts on Action against Trafficking in Human Beings (GRETA) provides a more detailed instrument to assess victim protection efforts than the 5 point sub-index of the 3P index [67: 239-240]. The GRETA scoring card is based on the legislative and institutional obligations of the 2005 Warsaw Convention. Therefore, availability of this measure is restricted to European countries. In addition, information is only available after 2011, which makes the scoring card unsuitable for the present study.

Hence, the following analyses employ the sub-index of "protection-policies" of the 3P Index as dependent variables despite the criticism associated with its information sources. Most of this critique only refers to the misuse of the tier-rankings produced by the US Department of State for foreign policy ends and not to the actual written information in the country narratives of the TIP Reports. It is important to stress that coding of the sub-index "protection policies" is solely based on written information given in the TIP reports and ignores the numerical tier rankings. A cross-validation of available measurements of governmental anti-trafficking efforts has shown that in Europe the scores of the 3P Anti-Trafficking Index widely reflects other measurements [67: 248].

\section{Independent variables}

Four variables were used to measure the descriptive and ideological composition of national parliaments and cabinets. The presence of women in parliament is measured by the percentage of parliamentary seats held by female parliamentarians, available

\footnotetext{
${ }^{3}$ For a detailed outline of the 3P Anti-Trafficking Index coding procedures, please see http://www.economicshuman-trafficking.org/mediapool/99/998280/data/Coding_Guideline.pdf (accessed 4 March 2015).
} 
from the Comparative Political Data Set III (CPSD III) [70]. The presence of left parties in cabinet is captured as a percentage of total cabinet posts of all government parties held by social democratic and other left-wing parties, weighted by the number of days the government was in office in a given year. This measure is also available in the CPSD III data [71: 6]. Two variables were calculated to assess overall parliament attitudes towards social justice and underprivileged minority groups. Data was used from the Comparative Manifesto Project (CMP) [62, 72, 73], which are based on a content analysis of party manifestos at national elections. The Manifesto Project calculates, for each party in parliament, how many sentences relative to the length of the overall party program are dedicated to 56 topical categories [73]. The two categories relevant to this paper are "social justice" which encompasses favourable references to the need for fair treatment of all people, special protection for underprivileged, the removal of class barriers, and "underprivileged minority groups", which circumscribes "favorable references to underprivileged minority groups who are defined neither in economic nor in demographic terms" [73]. Larger values of these variables indicate a more positive attitude towards social justice and underprivileged minorities. The overall proportion of parliamentary attitudes towards these two categories for each country and year were calculated following a two-step logic: first, the scores of each parliamentary party were weighted by the number of parliamentary seats held by this party. Second, the weighted scores of parliamentary parties were added for each national parliament to obtain the proportion of positive attitudes towards social justice and underprivileged minorities respectively. ${ }^{4}$

\section{Control variables}

Counter trafficking policies are not exclusively linked to left-wing and social democratic parties. Due to the prominent belief that human trafficking predominantly consists of illegal sex trade [55, 74, 75], conservative parties might find antitrafficking efforts to be a suitable justification for prohibiting prostitution. The same effect can be expected from parliaments endorsing law and order policies. Political parties, which devote large parts of their electoral manifestos to fighting crime, might try to push counter trafficking legislation in parliament, especially since the welfare of victims is often present in rhetoric concerned with tough action on crime [76: 93-141]. Hence, victim protection efforts might emerge as a by-product of counter-trafficking pursuits aimed at suppressing trafficking in persons. Consequently, the analysis controls for the presence of right wing parties in cabinet measured by their percentage of total cabinet posts taken from the CPSD III data, ${ }^{5}$ and parliamentary support for law and order, calculated analogous to the parliamentary attitudes towards social justice and underprivileged minorities using the CMP data.

\footnotetext{
${ }^{4}$ The data of the Comparative Manifesto Project are panel data using parties as unit. The measures hence had to be aggregated on country-year level. As a consequence, the two variables representing parliamentary attitudes towards social justice and underprivileged minorities only change values in years in which elections took place and are constant in between.

5 The CPS III Data distinguishes parties in three ideological categories: left-wing/ social democratic, rightwing, and centre. The presence of the percentage of both left- and right- wing parties in the model does therefore not introduce problems with multicollinearity, as this leaves the parties at the centre of the spectrum of political ideologies as reference category.
} 
Four institutional characteristics, which influence the policymaking process were controlled for. First, the existence of political constraints, for example rigid checks and balances, confine the ruling party's possibilities to introduce new policies at a national level. The political constraints measure by Henisz [77] records the feasibility of policy change. It captures "the extent to which any one political actor or the replacement for any one actor - e.g., the executive or a chamber of the legislature - is constrained in his or her choice of future policies.“ [78]. Second, corruption impairs a country's anti-trafficking efforts [30, 79]. Third and likewise, enforcement of policies to protect trafficking victims depends on the availability of monetary resources [67: 245]. Hence, Transparency International's Corruption Perception Index and the central government debt as percentage of GDP as available in the CPSD III [70] are included. ${ }^{6}$ Lastly and fourth, laws and policy practice are shaped by a country's legal origin [80]. This influence in turn can impact a country's likelihood to adopt and enforce comprehensive victim protection policies [11]. To this end the analysis includes a dummy variable to identify whether a country's legal origin lies in Civil Law (French, Scandinavian, and German Commercial Codes) as opposed to Socialist/ Communist or Common Law.

Models also control for a number of international factors. First, the type of trafficking a country is confronted with will likely shape counter-trafficking efforts $[9,16]$. Dummy variables capturing whether a country is predominantly affected by trafficking as either destination, origin, or transit state will be added to the analysis [69]. Furthermore, countries in Eastern Europe differ from the other sample countries in terms of political and economic pressures. A dummy variable indicating the location of a country in Eastern Europe is therefore included in the analysis.

Furthermore, by ratifying the UN Anti-Trafficking Protocol states indicate their awareness of human trafficking and its countermeasures. However, it may take some time before the ratification results in the enforcement of proceedings to protect victims of trafficking. Hence, the analysis contains a time variable counting the years since ratification of the protocol to control for a state's interest in suppressing human trafficking. ${ }^{7}$ Lastly, to account for the relevance of binding regional treaties to victim protection efforts a dummy variable to indicate whether a country has ratified the 2005 Warsaw Convention was included in all models. ${ }^{8}$

\section{Analytic strategy}

The data set has as a time-series-cross-section (tscs) structure with 396 country-year observations of 33 countries between the years 2000 and 2011. The data meet the minimum requirement of 10 repeated observations for pooled time series regressions [81: 274; 82: 332]. Values of the independent and dependent variables vary over time

\footnotetext{
${ }^{6}$ Government debt was standardized by subtracting the mean and dividing the result by the standard deviation to arrive at a range of values comparable to the other variables.

${ }^{7}$ For a systematic overview of the variables included in the multivariate analysis as well as their sources, see Table 3 in the Appendix.

${ }^{8}$ The EU Trafficking Directive as well as the judgement on Rantsev vs. Cyprus and Russia were omitted from the analysis as the documents came into effect in 2011 and 2010, respectively. Since effects of such treaties often show with some delay it was assumed that both decisions occurred too late in the observation period to exert an observable influence on the dependent variable within the analyses.
} 
and countries. ${ }^{9}$ Given the ordinal structure of the dependent variable, ordered logit regressions for pooled time series data were calculated. ${ }^{10}$ Standard errors were clustered on country level to take into account that observations from the same country are not independent from each other. The problem of autocorrelation is addressed by inclusion of a one-year lag of the dependent variable (LDV) as explanatory variable [81, 82]. The LDV may dominate the model's explanatory power [86: 231; 87: 336-343] but it can account for possible path dependency of protection policies: policy decisions about victim protection in a given year affect protection policies in the following year. The data do not suffer from multicollinearity. ${ }^{11}$ In order to check robustness of the results additional models with time-fixed effects and ordered probit regressions were run. Country fixed effects are not included, as they lead to biased, inconsistent and distorted estimates in ordered logit and probit and regressions [88: 407-408; 89: 1419-1423].

\section{Results}

Figure 1 displays the dispersion of protection efforts across the sample countries for each year. Over time the number of countries in the sample pursuing very strong efforts increases, whereas countries taking no action at all to protect victims of human trafficking are only found at the beginning of the observation period. The graph also shows that the sub-index protection is unavailable in a number of instances throughout the first 3 years of the observation period.

Figure 2 illustrates four exemplary trajectories of the implementation of victim protection within the sample countries: initial improvements with a later decline in efforts to protect trafficking victims (Bulgaria), high volatility and inconsistency of enforcement of victim protection policies (Japan), a clear trend to improve efforts to protect victims of human trafficking over the course of time (Slovenia), as well as stable and but declining efforts to protect trafficking victims (United Kingdom).

What information do these numerical values of the index convey? The original coding material of the index "protection" (the TIP and UNOCD Reports) reveals that common reasons for declines in the "protection" index scores within these four countries encompass failure to effectively identify victims of human trafficking and a lack of proactive endeavours to detect trafficking victims in risk populations [90: 124125; 91: 149-152; UNOCD 2009: 240-241]. In some instances victims were not identified as such and hence were wrongfully punished for breaching immigration

\footnotetext{
${ }^{9}$ For summary statistics between countries, within countries, and across time of the variables included in the multivariate analysis please see Table 4 in the Appendix. Furthermore, Figure 4 in the appendix shows the victim protection trajectories for all countries in the sample.

${ }^{10}$ Probit and logit regressions are a standard approach for dependent variables with only two possible outcomes. Ordered logit is a generalization of the standard logit model allowing more than two outcomes of the dependent variable [85]. The Brant Test of Parallel Regression Assumption indicates that the latter is only violated for the lagged dependent variable. This variable however is only used as a control for autocorrelation in the time series. Therefore ordered logistic regressions rather than multinomial or generalised ordered logit models were calculated.

${ }^{11}$ Collinearity statistics available from the author by request.
} 


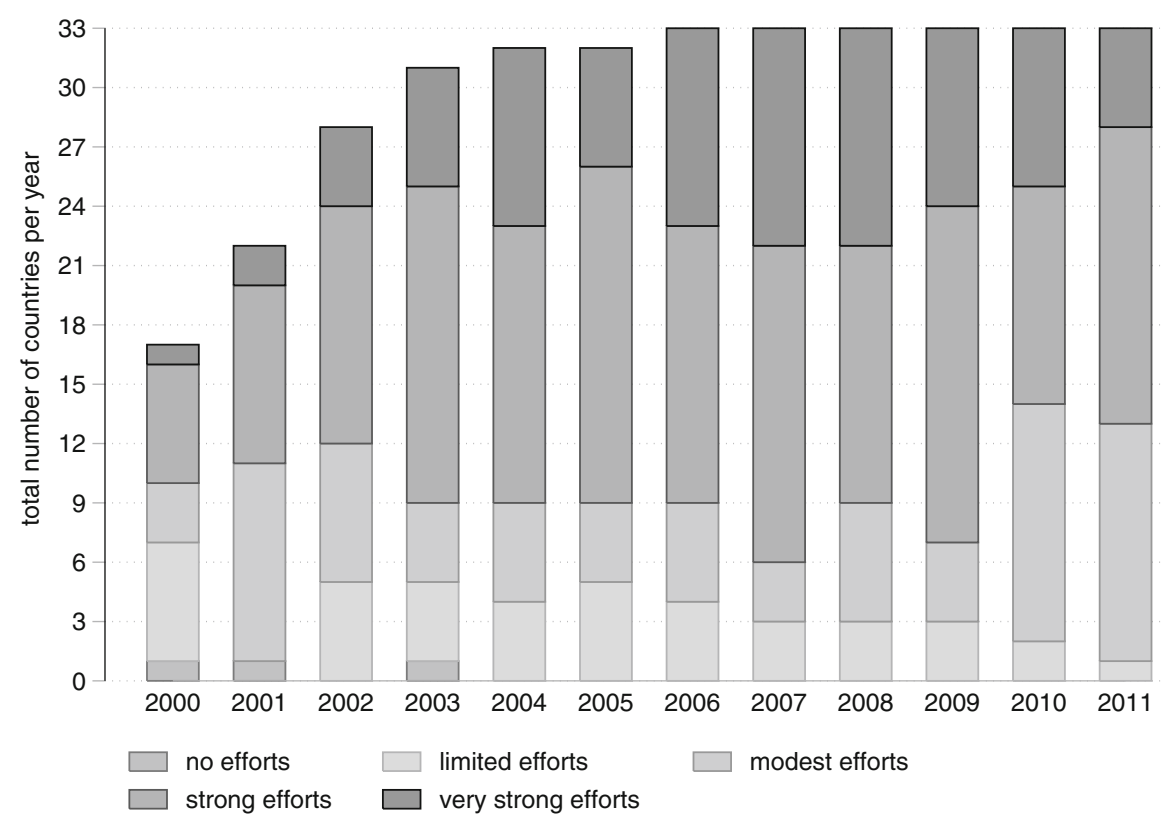

Fig. 1 Victim protection efforts by year

laws (United Kingdom in 2008, Japan in 2007) or crimes committed as a direct result of being trafficked $^{12}$ (Bulgaria in 2008) [90: 124-125; 91: 255-256; 92: 94-95]. The low index values for Bulgaria, Slovenia and Japan at the beginning of the observation period reflect the lack of governmental protection services caused by limited funds (Bulgaria and Slovenia), absence of witness protection capabilities (Bulgaria), refusal to acknowledge the victim status of trafficked persons (Japan), and the failure to financially support NGOs who work with trafficking victims (Japan) [31: 33; 93: 67; 52].

Slovenia's success in establishing a sustainable system of state shelters and its increasing collaboration with NGOs which offer counselling, legal support, and health care has lead the country on a path towards steady improvement of its score on the "protection" index [94: 136; 91: 227]. From 2008 onwards TIP reports describe Slovenia as "sustaining generous victim assistance" [91: 227] practicing formalized victim identification and referral mechanisms, granting amnesty to identified trafficking victims, offering a 90-day reflection period where victims can decide whether or not they would like to assist in prosecuting their traffickers, and paying annual funds of over $\$ 100,000$ to NGOs. These measures have been extended to provision of shelter, rehabilitative counselling, medical and legal assistance, as well as vocational training for trafficking victims and access to employment [7: 280-281]. The GRETA country report for Slovenia, which was published in 2014, confirms ongoing comprehensive victim protection efforts in Slovenia [95: 27-34]. However the Council of Europe group of experts see room for further improvement of victim protection measures in

\footnotetext{
${ }^{12}$ Examples for crimes as a direct result of human trafficking are prostitution in countries where prostitution is illegal but the victim is forced into it, or breaches of immigration law if the victim's nationality requires a visa in the destination country.
} 


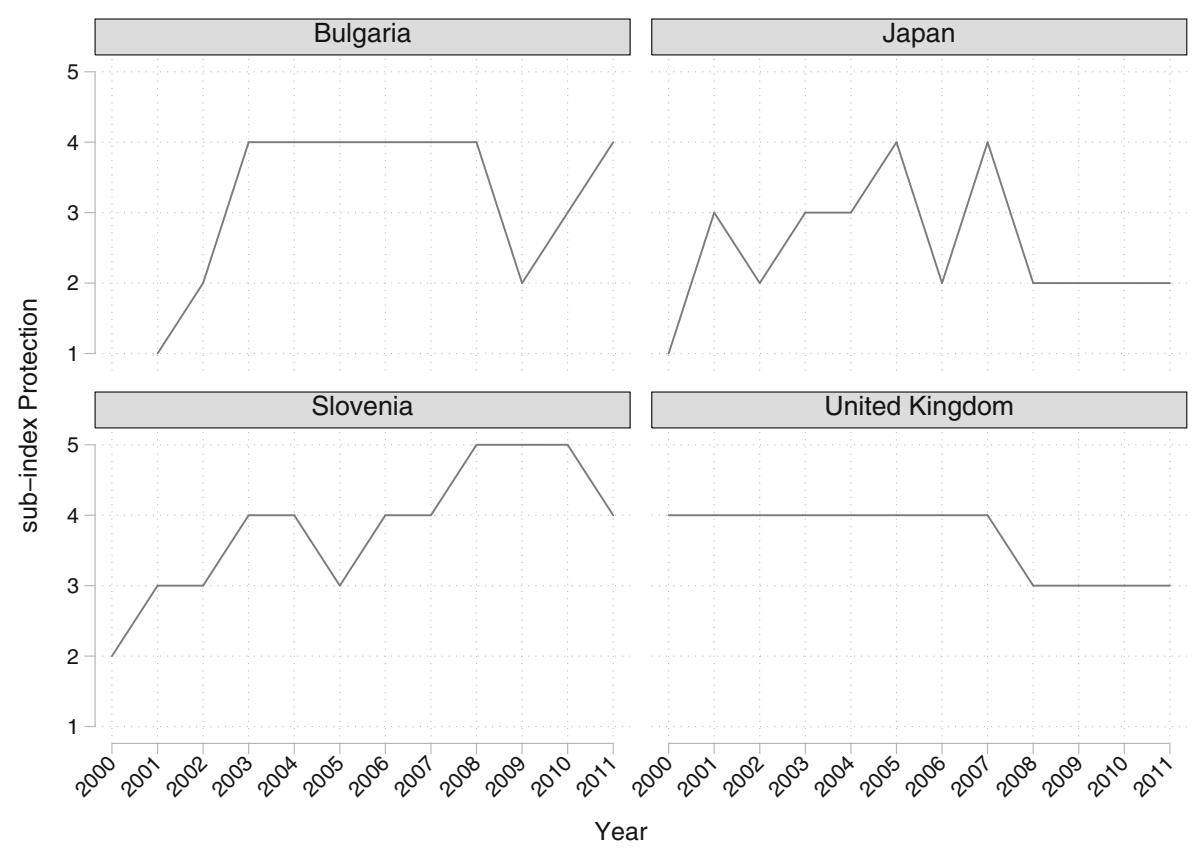

Fig. 2 Trajectories of victim protection in Bulgaria, Japan, Slovenia, and the United Kingdom 2000-2011

formalising the identification process for victims and in abolishing differences in the comprehensiveness of assistance and protection services contingent on the victims' willingness to assist in the investigation and prosecution of their traffickers [95:27, 30].

Starting from no victim protection at all, Japan displayed an "impressive start in providing assistance to victims, including the implementation of a national action plan" [96: 132] in early 2005. However, the government has repeatedly failed to comply with its own agenda. Protection measures are mainly tailored to accommodate women who are being trafficked for sexual exploitation purposes [7: 172].

Bulgaria gained index points in the mid-2000s through its passing of a bill to grant comprehensive victim assistance, its investment in building government run shelters for victims of trafficking and its close co-operation with anti-trafficking organizations [96: 128; 97: 89-90]. The more recent GRETA report of the first evaluation round reveals that towards the end of the observation period the most significant deficiencies in Bulgaria's protection scheme for trafficking victims lie in the lack of protection services for male victims, failure to identify unaccompanied minors as trafficking victims and the subsequent imposition of educational obligations rather than protective measures, as well as insufficient government funds to expand protection services beyond minimum provisions [98: 35-43].

The United Kingdom (UK) gained its positive ranking through funding antitrafficking NGOs providing shelter and counselling for victims and by establishing a "National Referral Mechanism" with clear operating procedures for officials encountering victims of human trafficking [97: 294-295; 99: 254].

However, some deficiencies have prevented the UK from attaining the best possible index scores: the shelters in operation are mainly streamlined to support female victims of sex trafficking [7: 292]. They do not admit trafficked children, victims of domestic 
servitude, and forced labour [97: 294-295]. Furthermore, the fate of child victims after leaving their foster-homes is unclear. Altogether, officials are criticized for not being proactive enough in identifying victims at important ports of entry to the country [90: 204-205]. Additionally, many services available in the United Kingdom's victim protection program are conditional on victims' willingness to assist in the prosecution of their traffickers [92: 337]. Harsh enforcement of anti-immigration laws in the UK have led to the prosecution of victims for breaching immigration laws, which resulted in a further downgrade on the protection index [97: 294-295]. Many of the deficiencies in victim protection efforts of the United Kingdom pointed out by the TIP reports were also addressed in the first round of the GRETA evaluation of UK anti-trafficking efforts [100: 49-72]. Especially the fact that in several instances unaccompanied minors who were potential trafficking victims were either deported back to the country they entered from within 24 hours without notifying child protection services, were put in detention for breaching immigration laws, or were placed in foster homes but subsequently went missing raised concern among members of GRETA [100: 57-59].

Table 1 reports results from the multivariate analysis. All columns show proportional odds calculated from ordered logit regression coefficients with standard errors in parentheses. The outcome in models 1 through 4 is the sub-index "protection" of Cho et al. [8] as described in the previous section. Model 1 contains the main independent variables. Model 2 adds two interaction effects between the share of left parties in cabinet and parliament's attitudes towards social justice and underprivileged minorities, respectively. Model 3 adds control variables. Model 4 introduces time fixed effects, which are not reported. ${ }^{13}$ All models contain a one-year lag of the dependent variable "protection" to account for autocorrelation. The significant Likelihood Ratio test statistics (LR) suggest that the predictor variables do have an effect on victim protection efforts in all four models. Nagelkerke's R shows proportions of explained variance between 50 and $60 \%$.

After list-wise deletion the number of observations for the multivariate analysis is reduced to 325 country year observations. 33 cases of these missing values can be attributed to the lagged dependent variable, as the LDV is missing for each country's first year observation since there is no data for the year preceding the first observation. Hence, the multivariate analysis only uses data from 2001 to 2011. In addition, the subindex "protection" is missing in a number of instances, especially at the beginning of the observation period, which further reduces the number of complete cases to 326. Early TIP reports contained fewer country narratives and those countries with missing data at the beginning of the observation period were not covered by those early TIP reports. Hence, no information about anti-trafficking efforts of these countries could be coded. However, none of the independent variables significantly predicts missing and non-missing cases on the dependent variable. There was only one complete case with a score of 1 on the sub-index "protection" (Greece in 2003), which was excluded from analyses so as not to distort results. ${ }^{14}$

\footnotetext{
${ }^{13}$ Available from author by request.

${ }^{14}$ Please find a table with bivariate relationships between independent and dependent variables in Table 5 in the Appendix.
} 
Table 1 Ordered logit regression (Pooled Analysis, Odds Ratios, Outcome = Index "Protection")

\begin{tabular}{|c|c|c|c|c|}
\hline Variables & Model 1 & Model 2 & Model 3 & Model 4 \\
\hline Protection(t-1) & $\begin{array}{l}5.816^{* * * *} \\
(1.399)\end{array}$ & $\begin{array}{l}5.639 * * * \\
(1.359)\end{array}$ & $\begin{array}{l}4.993 * * * \\
(1.184)\end{array}$ & $\begin{array}{l}5.629 * * * \\
(1.379)\end{array}$ \\
\hline Women in parliament (\% seats) & $\begin{array}{l}153.375^{* *} \\
(240.922)\end{array}$ & $\begin{array}{l}247.385 * * * \\
(406.250)\end{array}$ & $\begin{array}{l}53.370 * \\
(107.032)\end{array}$ & $\begin{array}{l}73.327^{*} \\
(149.855)\end{array}$ \\
\hline Left parties in cabinet (\% cabinet posts) & $\begin{array}{l}1.518 \\
(0.565)\end{array}$ & $\begin{array}{l}6.999 * \\
(5.335)\end{array}$ & $\begin{array}{l}23.778 * * \\
(24.023)\end{array}$ & $\begin{array}{l}18.990 * * \\
(19.456)\end{array}$ \\
\hline Parliament support for social justice & $\begin{array}{l}0.710 \\
(0.199)\end{array}$ & $\begin{array}{l}1.134 \\
(0.314)\end{array}$ & $\begin{array}{l}1.004 \\
(0.430)\end{array}$ & $\begin{array}{l}1.001 \\
(0.423)\end{array}$ \\
\hline Parliament support for minorities & $\begin{array}{l}1.499 \\
(1.037)\end{array}$ & $\begin{array}{l}1.854 \\
(1.420)\end{array}$ & $\begin{array}{l}0.798 \\
(0.693)\end{array}$ & $\begin{array}{l}0.922 \\
(0.763)\end{array}$ \\
\hline Left parties in cab.\#parl. support social justice & & $\begin{array}{l}0.171 * * \\
(0.108)\end{array}$ & $\begin{array}{l}0.112^{*} \\
(0.099)\end{array}$ & $\begin{array}{l}0.134 * \\
(0.123)\end{array}$ \\
\hline Left parties in cab.\#parl. support minorities & & $\begin{array}{l}0.455 \\
(0.500)\end{array}$ & $\begin{array}{l}0.284 \\
(0.376)\end{array}$ & $\begin{array}{l}0.270 \\
(0.371)\end{array}$ \\
\hline Right parties in cabinet (\% cabinet posts) & & & $\begin{array}{l}2.267 \\
(1.142)\end{array}$ & $\begin{array}{l}2.236 \\
(1.128)\end{array}$ \\
\hline Parliamet support for law and order & & & $\begin{array}{l}1.625 * * * \\
(0.237)\end{array}$ & $\begin{array}{l}1.551 * * \\
(0.219)\end{array}$ \\
\hline Political constraints & & & $\begin{array}{l}2.158 \\
(2.312)\end{array}$ & $\begin{array}{l}1.707 \\
(1.846)\end{array}$ \\
\hline Time since ratification & & & $\begin{array}{l}1.153 \\
(0.140)\end{array}$ & $\begin{array}{l}1.167 \\
(0.203)\end{array}$ \\
\hline Time since ratification (squared) & & & $\begin{array}{l}0.981 \\
(0.015)\end{array}$ & $\begin{array}{l}0.982 \\
(0.020)\end{array}$ \\
\hline Corruption perception index & & & $\begin{array}{l}0.910 \\
(0.146)\end{array}$ & $\begin{array}{l}0.914 \\
(0.145)\end{array}$ \\
\hline Government debt (\% gdp) & & & $\begin{array}{l}0.733 \\
(0.129)\end{array}$ & $\begin{array}{l}0.782 \\
(0.141)\end{array}$ \\
\hline Manily destination country & & & $\begin{array}{l}0.905 \\
(0.413)\end{array}$ & $\begin{array}{l}0.994 \\
(0.471)\end{array}$ \\
\hline Mainly transit country & & & $\begin{array}{l}0.827 \\
(0.381)\end{array}$ & $\begin{array}{l}0.775 \\
(0.363)\end{array}$ \\
\hline Eastern Europe & & & $\begin{array}{l}0.383 \\
(0.275)\end{array}$ & $\begin{array}{l}0.484 \\
(0.342)\end{array}$ \\
\hline Ratification Warsaw convention & & & $\begin{array}{l}1.018 \\
(0.304)\end{array}$ & $\begin{array}{l}1.024 \\
(0.326)\end{array}$ \\
\hline Legal origin: civil law & & & $\begin{array}{l}2.306^{*} \\
(0.828)\end{array}$ & $\begin{array}{l}2.284 * \\
(0.826)\end{array}$ \\
\hline Observations & 325 & 325 & 325 & 325 \\
\hline Nagelkerke $\mathrm{R}^{\wedge} 2$ & 0.551 & 0.562 & 0.589 & 0.606 \\
\hline LR Test & 229.384 & 236.427 & 253.625 & 264.675 \\
\hline Prob $>$ LR & 0.000 & 0.000 & 0.000 & 0.000 \\
\hline Year FE & No & No & No & Yes \\
\hline
\end{tabular}

Robust standard errors in parentheses; ${ }^{* * *} \mathrm{p}<0.001, * * \mathrm{p}<0.01, * \mathrm{p}<0.05$; table displays odds ratios 
Model 1 shows a significant coefficient of the LDV $(p<0.001)$, corresponding to the assumption that a country's victim protection procedures are path dependent: the enforcement of protection efforts in a given year is likely to shape a country's dealing with trafficking victims in the years to come. Model 1 furthermore corroborates evidence for a positive (significant) and strong link between women in parliament and the existence of comprehensive protection policies for trafficking victims, even if other parliament and cabinet characteristics are controlled for. In Model 2 the effects of protection efforts in the previous year and the share of women in parliament remain significant. The strength of the influence of women in parliament however shrinks when control variables and time-fixed effects are introduced to the analysis (Models 3 and 4).

In Model 2 a significant direct effect of left parties in cabinet $(p<0.05)$ emerges, which remains significant in the subsequent models. This lends support to the hypothesis that left parties in cabinet are positively associated with a country's efforts to protect trafficking victims (H.2). Only the interaction between left parties in cabinet and parliament support for social justice is significant, but contrary to expectations does not suggest a mutually reinforcing effect between the two variables: parliamentary support for social justice does not seem to enhance the association between left parties in government and victim protection efforts. To the contrary, the effect of left parties in cabinet on victim protection efforts weakens in the case of strong parliamentary support for social justice. The variables representing the ideological composition of parliament remain insignificant in Model 2 and the more restrictive Models 3 and 4. Hence, the present data do not corroborate the assumption that benevolent attitudes towards social justice and underprivileged minorities in parliament alone (H3.1 and H3.2) correspond to more comprehensive policies in the interest of trafficking victims.

Model 3 confirms that the findings of Model 2 are robust to the presence of control variables. Interestingly, not benevolent attitiudes towards social justice and underprivileged minorities but parliamentary support for law and order significantly coincide with the existence and enforcement of more comprehensive victim protection policies. The presence of right parties in cabinet however seems to be uncorrelated to victim protection efforts. Civil law countries are significantly more likely to display high scores on the protection index than common law or socialist ones. None of the other control variables shows a significant association with victim protection efforts. Time since ratification of the UN Anti-Trafficking Protocol indicates a u-shaped relationship between time passed since ratification and scores of the index "protection policies": protection efforts increase shortly after ratification of the protocol but then decrease the longer the ratification dates back. Ratification of the Council of Europe Warsaw Convention appears to be associated with more comprehensive compliance to the UN Anti-Trafficking Protocol, but not at conventional significance levels. Protection efforts are lower in the presence of government debt, high levels of corruption, as well as in Eastern European countries. These associations again are not significant at conventional levels. Lastly, results indicate that protection services for victims of human trafficking are not more comprehensive in transit or destination than in origin 
countries. Model 4 demonstrates that findings remain stable in the presence of time fixed effects. ${ }^{15}$

Figure 3 unpacks the significant interaction between the share of left parties in cabinet and parliament support for social justice. It demonstrates how the effect of the share of left-wing and social democratic parties in cabinet changes with various levels of parliamentary support for social justice for different levels of efforts to protect victims of human trafficking: limited efforts (Fig. 3.1), modest attempts (Fig. 3.2), strong efforts (Fig. 3.3), and very strong efforts (Fig. 3.4). ${ }^{16}$

Figure 3 shows that the interaction between the share of left parties in cabinet and parliamentary support for social justice is only significant for limited, modest, and very strong efforts (Figs. 3.1, 3.2, and 3.4) and is so only for very low levels of parliamentary support for social justice. In Fig. 3.3 (strong efforts to protect victims) as well as for higher levels of parliamentary support for social justice confidence intervals include zero, indicating that there is no significant interaction between left and social democratic governments and parliamentary support for social justice. What does this mean? Figures 3.1 and 3.2 show that the presence of left parties in cabinet reduces a country's probability to only make limited or modest attempts to protect victims of human trafficking. However this negative effect becomes increasingly attenuated the more parliamentary support for social justice exists. If left-wing parties in cabinet try to prevent only limited or modest protection for victims (presumably trying for stronger measures) then their efforts are thwarted by a parliament with high levels of support for social justice, presumably aiming for the more modest protection. In contrast, left parties in cabinet with no or only low levels of parliamentary support for social justice increase the probability of very strong victim protection efforts. Again, the presence of parliamentary support for social justice actually diminishes this effect. Taken together, the presence of parliamentary support for social justice seems to affect the policies of left and social- democratic parties in cabinet as they constrain options for a very strong protection of victims, and promote the more modest and limited approaches to which the left wing parties in government are opposed.

Against the background of these results it appears as though parliamentary support for social justice does not have the beneficial effect on victim protection efforts as expected in H3.1 and especially H4.1. Even though the provision of comprehensive protection services for victims of human trafficking thematically relates to social justice and support for underprivileged minorities, findings of this paper indicate that in practice victim protection is more closely related to criminal than social justice, as indicated by the positive effect of parliamentary support for the strict enforcement of law and order policies in models 3 and 4 of Table 1. National legislators thus seem to follow the crime framework established by the UN Anti-Trafficking Protocol rather than a social justice and minority-oriented agenda.

\footnotetext{
${ }^{15}$ The results of models 1 through 4 remain the same when calculating ordered probit instead of logit regressions (see Table 6 in the Appendix).

${ }^{16}$ Marginal effects were estimated on the basis of Model 3 in Table 1.
} 

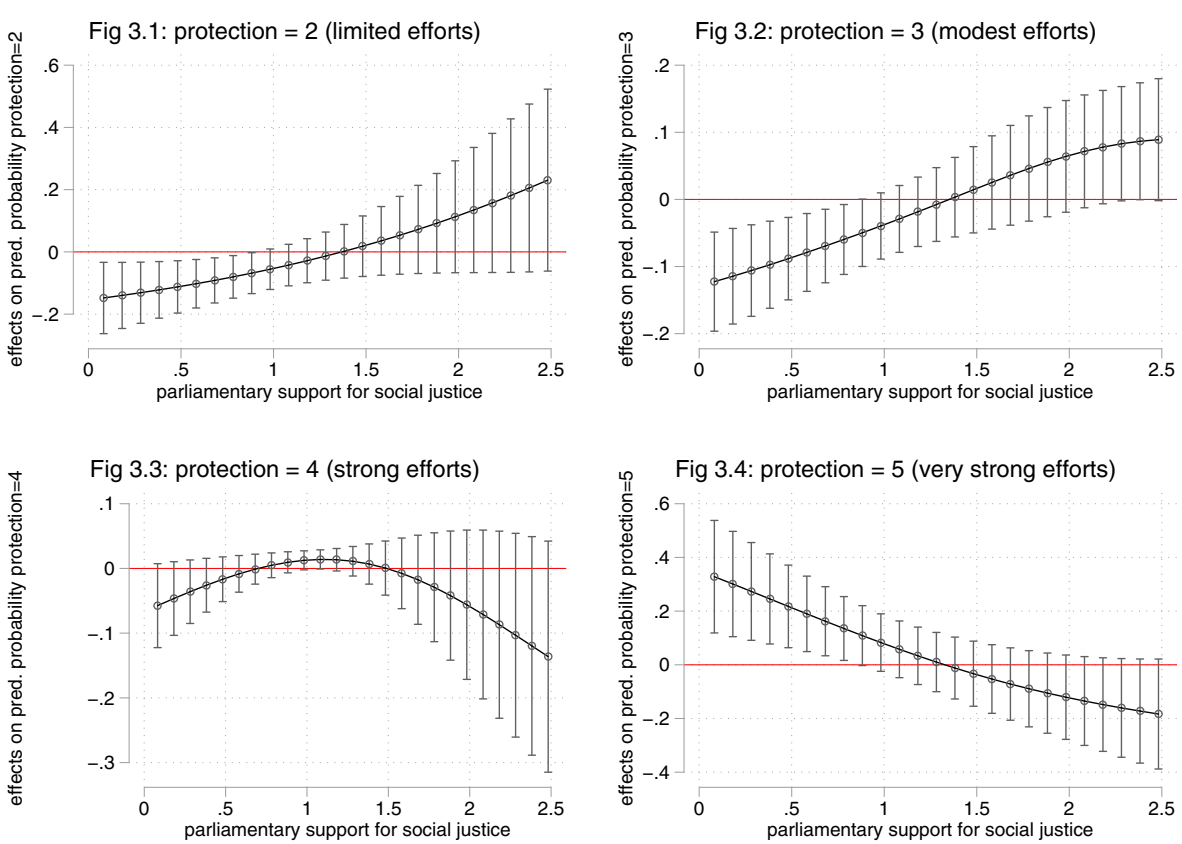

Fig. 3 Average marginal effects of left parties in cabinet at different degrees of parliamentary support for social justice (with $95 \%$ confidence intervals)

\section{Discussion and conclusion}

This study assessed the link between domestic political factors and compliance with victim protection as stipulated in the UN Anti-Trafficking Protocol in a sample of 33 countries from 2000 to 2011. It contributes to the broader question as to what drives compliance with international treaties lacking enforcement mechanisms: is compliance only caused by international actors and power politics, or can local actors also contribute to shaping the implementation and enforcement of policies [101]? The results showed that certain characteristics of national cabinets and parliaments are indeed significantly associated with more comprehensive policy efforts to protect victims of human trafficking.

The consistently positive relationship between female parliamentarians and the existence and enforcement of comprehensive policies to assist victims in human trafficking confirms the results of previous research $[9,12,14]$.

Nevertheless, this study advances our knowledge of the substantive representation of minority interests by female members of parliament: the gender effect remains stable and significant even when other parliamentary and government features, which are conducive to the protection of trafficking victims are controlled for.

The multivariate analysis identified additional significant effects of government parties and the ideological composition of parliament: first, left-wing and social democratic parties in cabinet coincide with strong efforts to accommodate, counsel and assist victims of trafficking in human beings. Yet, the effect of left parties in cabinet also depends on the parliament as an important player. 
Contrary to assumptions this positive effect of left parties in cabinet is most visible when there are low levels of parliamentary support for social justice. However, high levels of parliamentary support for the strict enforcement of law and order policies promote higher levels of efforts to protect victims of human trafficking. These findings suggest that compliance with the dimension of victim protection is more driven by a law- and order agenda than by a social justice agenda. This reflects the framing of the UN Anti-Trafficking Protocol as a crime fighting rather than human rights document. Even compliance to the Protocol's neglected area of victim protection is advanced by parliaments composed of political parties on whose agenda crime and the strict enforcement of criminal justice policies is a salient topic, and who thus buy into the crime framework of the UN Anti-Trafficking Protocol. Even though the dimension of victim protection thematically aligns with support for social justice or underprivileged minorities more generally, this agenda might actually be driven by a more parochial welfare agenda, which is inimical to newcomers and protects welfare provision for national citizens. Therefore the results demonstrate that even if social justice is widely supported in parliament, its members are cautious in supporting the most far-reaching and comprehensive measures. Lastly, countries with a legal origin in civil law show higher levels of compliance with the UN Anti Trafficking Protocol's dimension of victim protection.

A caveat is necessary here: the UN Anti-Trafficking Protocol grants its ratifying states a high level of discretion regarding the policy dimension of victim protection, as Articles 6 to 8 more strongly resemble recommendations than obligations. For this reason, governments can design their protection policies to firstly meet the circumstances they see themselves confronted with, and secondly according to their own beliefs of best practice. If countries experience that enforcement of generous victim protection policies serves as an incentive for illegal immigrants to pretend they are victims of human trafficking, they may easily cut back their protection efforts or make them more restrictive (plausibly because of the popular voter backlash). This optional character of the particular policy dimension of victim protection may render domestic political factors like the ones identified in this study more significant. Their influence may be less decisive regarding prevention and prosecution, since these policy dimensions are formulated as obligations.

The results of this study yield important implications: firstly, future analyses should not leave aside domestic political circumstances, actors, and their interplay when trying to explain compliance with international treaties. Secondly, this paper can serve as a basis for further qualitative in depth analyses on the role of the administration and judiciary for the implementation of policies to protect and support trafficking victims. The ordinal structure of the five-point scale index of protection policies can only give a general account of how important the welfare of trafficking victims is deemed in each country within the sample [102]. ${ }^{17}$ Future research should thus aim at a more refined measurement of victim protection

\footnotetext{
${ }^{17}$ See also a recent article on performance indices in The Economist (8th November 2014): http://www. economist.com/news/leaders/21631025-learn-ruses-international-country-rankings-how-lie-indices (accessed 17 Nov 2014).
} 
efforts, such as the new measure constructed from reports of the European Council's Group of Experts on Action Against Trafficking [67] or data available in the "Human Trafficking Indicators Database" [84]. In this vein a further avenue for future research is to look in more detail into different groups of trafficking victims and their access to victim protection services. The GRETA reports cited in this study imply that the provision and especially comprehensiveness of protection services varies greatly among groups of victims defined by victim characteristics or purposes of trafficking. Especially males and (unaccompanied) minors have been identified to be a disadvantaged group of victims in terms of access to protection services even in environments where these were widely available for other groups and rated as "strong" by the protection index used in this study (e.g. United Kingdom). Similar mechanisms might be found in relation to domestic vs. foreign trafficking victims as well as victims who have been identified as such by a country different from the one providing protection to the victim (e.g. repatriated victims to Slovenia).

Future research should also focus on a more detailed analysis of the independent variables of this study as well as further potential domestic influences which might drive compliance with the UN Anti-Trafficking Protocol's dimension of victim protection: do female parliamentarians feel a special "compassionate solidarity" [103: 459] and responsibility towards trafficking victims due to the phenomenon's reputedly gendered nature? Or is human trafficking a policy area over which women in politics can individuate and build up a profile for themselves? Either way against the background of the GRETA reports suggesting that protection efforts for women are generally superior to those in place for men the role of female policy makers deserves closer and more qualitative attention. Extensive analyses of parliamentary behaviour of female members of parliament - such as their roll call history on legislative proposals related to trafficking - can provide more fine-grained insights. Case studies about legislative proposals and votes in regards to human trafficking and victim protection could also shed more light on the role of government parties and their ideational alignment. In addition, the role of social justice agendas needs more research attention: when and how do welfare and social justice policies become exclusive, and which minority groups are included and which are not. These are questions that address the importance of solidarity values in social justice policies and agendas, as well as public support for them.

Further potential drivers of compliance with victim protection efforts that should be explored further are the role of particular trafficking patterns in a country as well as the influence of regional guidelines as addressed in earlier sections. This study has only assessed the influence of the Warsaw Convention, which is owed to the observation period that ended in 2011. Now that the EU Trafficking Directive as well as the judgement of Rantsev vs. Cyprus and Russia have been effective for more than 5 years it is possible that these constitute further important operators for compliance with victim protection as stipulated in the UN Anti-Trafficking Protocol. The Warsaw Convention and the EU Trafficking Directive however also deserve attention in their own right: is compliance to those treaties affected by similar mechanisms to the ones identified in this paper? In which ways do particular forms of trafficking patterns 
(e.g. domestic trafficking, trafficking for sexual exploitation, trafficking for forced labour) impact on the landscape of victim protection measures that are put in place?

Lastly, future research should investigate the role of domestic political factors for the two other policy dimensions addressed in the UN AntiTrafficking Protocol: are government characteristics less important for compliance to prevention and prosecution, because states have a lower level of discretion regarding the implementation of these policy dimensions in their domestic legislation and practices?

The results of this study suggest that the fate of trafficking victims is not entirely a product of international power politics and interests. It is also the result of complex interactions on the local level between governments, parliaments and the legal system, the different interests and agendas of actors, and the structures in which they operate.

Acknowledgments I would like to thank Peter Wetzels and Dirk Enzmann (University of Hamburg), Susanne Karstedt (Griffith University), and the anonymous reviewers for their comments which greatly helped to improve previous iterations of this manuscript.

\section{Compliance with ethical standards}

Funding This work was supported by the Economic and Social Research Council [ES/J500215/1].

Conflict of interest The authors declare that they have no conflict of interest.

\section{Appendix 1}

Table 2 List of countries in the sample

\begin{tabular}{lll}
\hline Australia & Germany & Norway \\
Austria & Greece & Poland \\
Belgium & Hungary & Portugal \\
Bulgaria & Ireland & Romania \\
Canada & Italy & Slovakia \\
Cyprus & Japan & Slovenia \\
Czech Republic & Latvia & Spain \\
Denmark & Lithuania & Sweden \\
Estonia & Luxembourg & Switzerland \\
Finland & Netherlands & United Kingdom \\
France & New Zealand & USA \\
& & \\
\hline
\end{tabular}


Table 3 Variables, description, and sources

\begin{tabular}{|c|c|}
\hline Variable & Description \\
\hline $\begin{array}{l}\text { Sub index } \\
\text { "protection" }\end{array}$ & $\begin{array}{l}\text { Protection policy measure based on } \\
\text { victim protection as prescribed in the } \\
\text { Palermo Protocol. } 5 \text { point scale: } 1=\text { no } \\
\text { effort; } 2=\text { limited efforts; } 3=\text { modest } \\
\text { attempts; } 4=\text { strong efforts; } 5=\text { very } \\
\text { strong efforts }\end{array}$ \\
\hline $\begin{array}{l}\text { Women in parliament } \\
\text { (\% seats })\end{array}$ & $\begin{array}{l}\text { Percentage of women in parliaments at } \\
\text { the end of the corresponding year }\end{array}$ \\
\hline $\begin{array}{l}\text { Left parties in cabinet } \\
\text { (\% cabinet posts })\end{array}$ & $\begin{array}{l}\text { Cabinet composition: social democratic } \\
\text { and other left-wing parties as a per- } \\
\text { centage of total cabinet posts, weighted } \\
\text { by the number of days the government } \\
\text { was in office in a given year }\end{array}$ \\
\hline $\begin{array}{l}\text { Parliament support for } \\
\text { social justice }\end{array}$ & $\begin{array}{l}\text { Ratio of favourable references in party } \\
\text { manifestos to the need of fair treatment } \\
\text { of all people, special protection for } \\
\text { underprivileged, the removal of class } \\
\text { barriers etc. of all parliamentary parties } \\
\text { in a given year weighted by the } \\
\text { number of parliamentary seats held by } \\
\text { each party }\end{array}$ \\
\hline
\end{tabular}

Parliament support for minorities

Right parties in cabinet (\% parl. Seats)

Parliament support for law and order

Henisz policical constraints index

Time since ratification groups who are defined neither in economic nor in demographic terms of all parliamentary parties in a given year weighted by the number of parliamentary seats held by each party

Cabinet composition: right-wing parties as a percentage of total cabinet posts, weighted by the number of days the government was in office in a given year

Ratio of favourable references in party manifestos to enforcement of all laws; actions against crime; support and resources for police; tougher attitudes in courts etc. of all parliamentary parties in a given year weighted by the number of parliamentary seats held by each party

Measure to estimate the feasibility of policy change considering the restrictions on executives. Higher scores indicate stronger political constraints

Count variable indicating the years which
Source

Cho et al. [8]

Armingeon et al. [70]: Comparative Political Data Set III; Codebook: Armingeon et al. [71]

Armingeon et al. [70]: Comparative Political Data Set III; Codebook: Armingeon et al. [71]

Own calculation based on the data of the Manifesto Project $[73 ; 72 ; 62]$ (variable per503)

Own calculation based on data of the Manifesto Project [73; 72; 62] (variable per705) have passed since a country's ratification of the UN Anti-Trafficking Protocol for each year. Starts with 1 in the ratification year. 0 if Protocol has not yet been ratified in a given year
Armingeon et al. [70]: Comparative Political Data Set III; Codebook: Armingeon et al. [71]

Own calculation based on data of the Manifesto Project $[73 ; 72 ; 62]$ (variable per605)

Henisz [77]; Henisz and Zelner [78]

Own coding, based on https://treaties. un.org/Pages/ViewDetails.aspx? $\mathrm{src}=$ TREATY \&mtdsg_no $=$ XVIII12 -a\&chapter $=18 \&$ lang $=$ en 
Table 3 (continued)

\begin{tabular}{ll}
\hline Variable & Description \\
\hline $\begin{array}{l}\text { Corruption perception } \\
\text { index }\end{array}$ & $\begin{array}{c}\text { The CPI of Transparency International } \\
\text { Score relates to perceptions of the } \\
\text { degree of corruption as seen by } \\
\text { business people, risk analysts and the } \\
\text { general public and ranges between 10 } \\
\text { (highly clean) and 0 (highly corrupt) }\end{array}$ \\
$\begin{array}{c}\text { Government debt } \\
\text { (\% of gdp) } \\
\text { percentage of GDP }\end{array}$ \\
$\begin{array}{c}\text { Mainly destination } \\
\text { country }\end{array}$ \\
$\begin{array}{c}\text { Dummy variable, 1 if country is mainly } \\
\text { destination country for human } \\
\text { trafficking }\end{array}$
\end{tabular}

Mainly transit country

Mainly origin country

Eastern Europe

Ratification Warsaw
convention

Legal origin: civil law
Dummy variable, 1 if country is mainly transit country for human trafficking

Dummy variable, 1 if country is mainly origin country for human trafficking

Dummy variable, 1 if country is situated in Eastern Europe

Dummy variable, 1 if country has ratified 2005 Council of Europe Convention Against Trafficking in Human Beings (Warsaw Convention)

Dummy variable, 1 if a country's legal origin lies in Commercial Code (French, German, or Scandinavian), 0 if a country's legal origin is English Common Law or Socialist/Communist Law
Source

The Quality of Government Basic Dataset Version 21 May 2012 [83]

Armingeon et al. [70]: Comparative Political Data Set III; Codebook: Armingeon et al. [71]

Own calculation based on Frank [84] (variable destination_order), supplemented with information from the Appendix of [5] in instances where the Human Trafficking Indicators Database (HTI) did not provide the data.

Own calculation based on Frank [84] (variable transit_order), supplemented with information from the Appendix of [5] in instances where the Human Trafficking Indicators Database (HTI) did not provide the data.

Own calculation based on Frank [84] (variable source_order), supplemented with information from the Appendix of [5] in instances where the Human Trafficking Indicators Database (HTI) did not provide the data.

Own coding, based on whether country was a former communist country (BGR, CZE, HUN, POL, ROM, SVN, SVK, LVA, LIT, EST)

Own coding, based on http://www. coe.int/en/web/conventions/fulllist/-/conventions/treaty/197/ signatures?p_auth=JzCkvPR1 (accessed 26 May 2016)

Own caluclation based on data from The Quality of Government Basic Dataset Version 21 May 2012 [83] (variable lp_lego) 
Table 4 Summary statistics of variables in multivariate analysis

\begin{tabular}{|c|c|c|c|c|c|c|}
\hline Variable & & Mean & Std. Dev. & Min & Max & Observations \\
\hline \multirow{3}{*}{$\begin{array}{l}\text { Sub index } \\
\text { „protection“ }\end{array}$} & overall & \multirow[t]{3}{*}{3.772 .222} & .9519401 & 1 & 5 & $\mathrm{~N}=360$ \\
\hline & between & & .6927895 & 2.333 .333 & 4.916 .667 & $\mathrm{n}=33$ \\
\hline & within & & .650966 & 1.499 .495 & 5.438 .889 & T-bar $=10.9091$ \\
\hline \multirow{3}{*}{$\begin{array}{l}\text { Women in parliament } \\
\text { (\% seats) }\end{array}$} & overall & \multirow[t]{3}{*}{.2290813} & .1006965 & .071 & .473 & $N=396$ \\
\hline & between & & .0979326 & .0889 & .4530667 & $\mathrm{n}=33$ \\
\hline & within & & .0285672 & .1155813 & .4078313 & $\mathrm{~T}=12$ \\
\hline \multirow{3}{*}{$\begin{array}{l}\text { Left parties in cabinet } \\
\text { (\% cabinet posts) }\end{array}$} & overall & \multirow[t]{3}{*}{.3427657} & .3647292 & 0 & 1 & $\mathrm{~N}=396$ \\
\hline & between & & .2273602 & 0 & .8648417 & $\mathrm{n}=33$ \\
\hline & within & & .2877052 & -.522076 & 1.147 .332 & $\mathrm{~T}=12$ \\
\hline \multirow{3}{*}{$\begin{array}{l}\text { Parliament support } \\
\text { for social justice }\end{array}$} & overall & \multirow[t]{3}{*}{.7567257} & .4656563 & .0819237 & 2.540 .941 & $N=396$ \\
\hline & between & & .3964287 & .2540046 & 1.848 .362 & $\mathrm{n}=33$ \\
\hline & within & & .2530939 & .1299998 & 176.114 & $\mathrm{~T}=12$ \\
\hline \multirow{3}{*}{$\begin{array}{l}\text { Parliament support } \\
\text { for minorities }\end{array}$} & overall & \multirow[t]{3}{*}{.204839} & .2220006 & 0 & 1.104 .333 & $\mathrm{~N}=396$ \\
\hline & between & & .1856566 & .0333197 & .9524725 & $\mathrm{n}=33$ \\
\hline & within & & .1256016 & -.2313487 & .5507973 & $\mathrm{~T}=12$ \\
\hline \multirow{3}{*}{$\begin{array}{l}\text { Right parties in } \\
\text { cabinet ( } \% \text { cabinet } \\
\text { posts) }\end{array}$} & overall & \multirow[t]{3}{*}{.4308843} & .3656653 & 0 & 1 & $\mathrm{~N}=396$ \\
\hline & between & & .2263515 & 0 & .8856167 & $\mathrm{n}=33$ \\
\hline & within & & .28966 & -.2834323 & 1.295 .726 & $\mathrm{~T}=12$ \\
\hline \multirow{3}{*}{$\begin{array}{l}\text { Parliamet support for } \\
\text { law and order }\end{array}$} & overall & \multirow[t]{3}{*}{.920759} & .8160259 & 0 & 6.406 .714 & $\mathrm{~N}=396$ \\
\hline & between & & .6761093 & .2306212 & 4.081 .363 & $\mathrm{n}=33$ \\
\hline & within & & .4706426 & -105.204 & 3.246 .111 & $\mathrm{~T}=12$ \\
\hline \multirow[t]{3}{*}{ Political constraints } & overall & \multirow[t]{3}{*}{.4618604} & .1153753 & .13334 & .72 & $\mathrm{~N}=396$ \\
\hline & between & & .0901059 & .253346 & .7066298 & $\mathrm{n}=33$ \\
\hline & within & & .0736103 & -.0090976 & .7285404 & $\mathrm{~T}=12$ \\
\hline \multirow{3}{*}{$\begin{array}{l}\text { Time since } \\
\text { ratification }\end{array}$} & overall & \multirow[t]{3}{*}{2.691 .919} & 2.993 .839 & 0 & 11 & $\mathrm{~N}=396$ \\
\hline & between & & 1.478 .357 & 0 & 05. Mai & $\mathrm{n}=33$ \\
\hline & within & & 2.615 .033 & -2.808 .081 & 8.191 .919 & $\mathrm{~T}=12$ \\
\hline \multirow{3}{*}{$\begin{array}{l}\text { Corruption perception } \\
\text { index }\end{array}$} & overall & \multirow[t]{3}{*}{6.812 .107} & 1.974 .011 & 2.6 & 10 & $N=393$ \\
\hline & between & & 1.963 .926 & 3.226 .012 & 9.508 .661 & $\mathrm{n}=33$ \\
\hline & within & & .351999 & 5.771 .487 & 804.599 & $\mathrm{~T}-\mathrm{bar}=11.9091$ \\
\hline \multirow{3}{*}{$\begin{array}{l}\text { Government debt } \\
\quad \text { (\% gdp) }\end{array}$} & overall & \multirow[t]{3}{*}{$-2.35 e-09$} & 1 & -1.434 .789 & 428.219 & $\mathrm{~N}=396$ \\
\hline & between & & .9643134 & -1.369 .321 & 3.099 .426 & $\mathrm{n}=33$ \\
\hline & within & & .3098315 & -.8711491 & 1.536 .535 & $\mathrm{~T}=12$ \\
\hline \multirow{3}{*}{$\begin{array}{l}\text { Mainly destination } \\
\text { coutry }\end{array}$} & overall & \multirow[t]{3}{*}{.5176768} & .5003196 & 0 & 1 & $\mathrm{~N}=396$ \\
\hline & between & & .4154971 & 0 & 1 & $\mathrm{n}=33$ \\
\hline & within & & .2872098 & -.3989899 & 135.101 & $\mathrm{~T}=12$ \\
\hline \multirow{3}{*}{$\begin{array}{l}\text { Mainly transit } \\
\text { country }\end{array}$} & overall & .1868687 & .3902992 & 0 & 1 & $\mathrm{~N}=396$ \\
\hline & between & & .275623 & 0 & .9166667 & $\mathrm{n}=33$ \\
\hline & within & & .2801446 & -.729798 & 1.103 .535 & $\mathrm{~T}=12$ \\
\hline Eastern Europe & overall & .3030303 & .4601496 & 0 & 1 & $\mathrm{~N}=396$ \\
\hline & between & & .4666937 & 0 & 1 & $\mathrm{n}=33$ \\
\hline
\end{tabular}


Table 4 (continued)

\begin{tabular}{|c|c|c|c|c|c|c|}
\hline Variable & & Mean & Std. Dev. & Min & Max & Observations \\
\hline \multirow{4}{*}{$\begin{array}{l}\text { Warsaw convention } \\
\text { ratified }\end{array}$} & within & \multirow{4}{*}{.1742424} & 0 & .3030303 & .3030303 & $\mathrm{~T}=12$ \\
\hline & overall & & .3797977 & 0 & 1 & $\mathrm{~N}=396$ \\
\hline & between & & .1784429 & 0 & .5 & $\mathrm{n}=33$ \\
\hline & within & & .3365875 & -.3257576 & 1.007 .576 & $\mathrm{~T}=12$ \\
\hline \multirow[t]{3}{*}{ Legal origin: civil law } & overall & \multirow[t]{3}{*}{.4848485} & .5004026 & 0 & 1 & $\mathrm{~N}=396$ \\
\hline & between & & .5075192 & 0 & 1 & $\mathrm{n}=33$ \\
\hline & within & & 0 & .4848485 & .4848485 & $\mathrm{~T}=12$ \\
\hline
\end{tabular}

Table 5 Bivariate correlation (Spearman) between independent and dependent variables (t-statistics in parentheses)

Protection

Protection (t-1)

$0.7142(0.0000)$

Women in parliament (\% seats)

$0.4738(0.0000)$

Left parties in cabinet (\% cabinet posts)

$0.1324(0.0169)$

Parliamentary support for social justice

$-0.0530(0.3411)$

Parliamentary support for minorities

$0.0765(0.1691)$

Right parties in cabinet (\% cabinet posts)

$-0.1068(0.0545)$

Parliament support for law and order

$-0.1061(0.0560)$

Political constraints

$0.0252(0.6504)$

Time since ratification

$0.1171(0.0349)$

Corruption perception index

$0.3263(0.0000)$

Government debt (\% of GDP)

$0.0675(0.2251)$

Mainly destination country

$0.1818(0.0010)$

Mainly tranist country

$-0.0270(0.6271)$

Eastern Europe

$-0.3264(0.0000)$

Warsaw convention ratified

$-0.0093(0.8679)$

Legal origin: Civil law

$0.3422(0.0000)$ 
Table 6 Ordered probit regression (Pooled Analysis, Outcome = Index "Protection")

\begin{tabular}{|c|c|c|c|c|}
\hline Variables & Model 1 & Model 2 & Model 3 & Model 4 \\
\hline Protection(t-1) & $\begin{array}{l}0.947 * * * \\
(0.123)\end{array}$ & $\begin{array}{l}0.933 * * * \\
(0.124)\end{array}$ & $\begin{array}{l}0.881 * * * \\
(0.125)\end{array}$ & $\begin{array}{l}0.934 * * * \\
(0.125)\end{array}$ \\
\hline Women in parliament (\% seats) & $\begin{array}{l}2.964 * * * \\
(0.897)\end{array}$ & $\begin{array}{l}3.146^{* * * *} \\
(0.933)\end{array}$ & $\begin{array}{l}2.243 * \\
(1.112)\end{array}$ & $\begin{array}{l}2.323^{*} \\
(1.163)\end{array}$ \\
\hline Left parties in cabinet (\% cabinet posts) & $\begin{array}{l}0.247 \\
(0.216)\end{array}$ & $\begin{array}{l}1.044^{*} \\
(0.452)\end{array}$ & $\begin{array}{l}1.785 * * \\
(0.583)\end{array}$ & $\begin{array}{l}1.700 * * \\
(0.599)\end{array}$ \\
\hline Parliament support for social justice & $\begin{array}{l}-0.148 \\
(0.156)\end{array}$ & $\begin{array}{l}0.101 \\
(0.153)\end{array}$ & $\begin{array}{l}0.045 \\
(0.237)\end{array}$ & $\begin{array}{l}0.065 \\
(0.233)\end{array}$ \\
\hline Parliament support for minorities & $\begin{array}{l}0.131 \\
(0.357)\end{array}$ & $\begin{array}{l}0.196 \\
(0.396)\end{array}$ & $\begin{array}{l}-0.261 \\
(0.451)\end{array}$ & $\begin{array}{l}-0.204 \\
(0.421)\end{array}$ \\
\hline Left parties in cab.\#parl. support social justice & & $\begin{array}{l}-0.976^{*} \\
(0.388)\end{array}$ & $\begin{array}{l}-1.250 * \\
(0.514)\end{array}$ & $\begin{array}{c}-1.192 * \\
(0.553)\end{array}$ \\
\hline Left parties in cab.\#parl. support minorities & & $\begin{array}{l}-0.264 \\
(0.589)\end{array}$ & $\begin{array}{l}-0.661 \\
(0.723)\end{array}$ & $\begin{array}{l}-0.659 \\
(0.748)\end{array}$ \\
\hline Right parties in cabinet (\% cabinet posts) & & & $\begin{array}{l}0.473 \\
(0.262)\end{array}$ & $\begin{array}{l}0.467 \\
(0.266)\end{array}$ \\
\hline Parliamet support for law and order & & & $\begin{array}{l}0.285^{* *} \\
(0.090)\end{array}$ & $\begin{array}{l}0.264 * * \\
(0.088)\end{array}$ \\
\hline Political constraints & & & $\begin{array}{l}0.511 \\
(0.657)\end{array}$ & $\begin{array}{l}0.430 \\
(0.652)\end{array}$ \\
\hline Time since ratification & & & $\begin{array}{l}0.081 \\
(0.072)\end{array}$ & $\begin{array}{l}0.096 \\
(0.097)\end{array}$ \\
\hline Time since ratification (squared) & & & $\begin{array}{l}-0.012 \\
(0.009)\end{array}$ & $\begin{array}{l}-0.013 \\
(0.011)\end{array}$ \\
\hline Corruption perception index & & & $\begin{array}{l}-0.054 \\
(0.091)\end{array}$ & $\begin{array}{l}-0.053 \\
(0.091)\end{array}$ \\
\hline Government debt (\% gdp) & & & $\begin{array}{l}-0.193 \\
(0.103)\end{array}$ & $\begin{array}{l}-0.178 \\
(0.101)\end{array}$ \\
\hline Manily destination country & & & $\begin{array}{l}-0.016 \\
(0.247)\end{array}$ & $\begin{array}{l}0.028 \\
(0.264)\end{array}$ \\
\hline Mainly transit country & & & $\begin{array}{l}-0.080 \\
(0.252)\end{array}$ & $\begin{array}{l}-0.096 \\
(0.253)\end{array}$ \\
\hline Eastern Europe & & & $\begin{array}{l}-0.566 \\
(0.395)\end{array}$ & $\begin{array}{l}-0.463 \\
(0.386)\end{array}$ \\
\hline Ratification Warsaw convention & & & $\begin{array}{l}0.040 \\
(0.162)\end{array}$ & $\begin{array}{l}0.038 \\
(0.170)\end{array}$ \\
\hline Legal origin: civil law & & & $\begin{array}{l}0.460 * \\
(0.186)\end{array}$ & $\begin{array}{l}0.462 * \\
(0.190)\end{array}$ \\
\hline Observations & 325 & 325 & 325 & 325 \\
\hline Nagelkerke $\mathrm{R}^{\wedge} 2$ & 0.540 & 0.550 & 0.582 & 0.596 \\
\hline LR Test & 222.962 & 229.150 & 248.696 & 258.068 \\
\hline Prob $>$ LR & 0.000 & 0.000 & 0.000 & 0.000 \\
\hline Year FE & NO & NO & NO & YES \\
\hline
\end{tabular}

Robust standard errors in parentheses; *** $\mathrm{p}<0.001, * * \mathrm{p}<0.01, * \mathrm{p}<0.05$ 


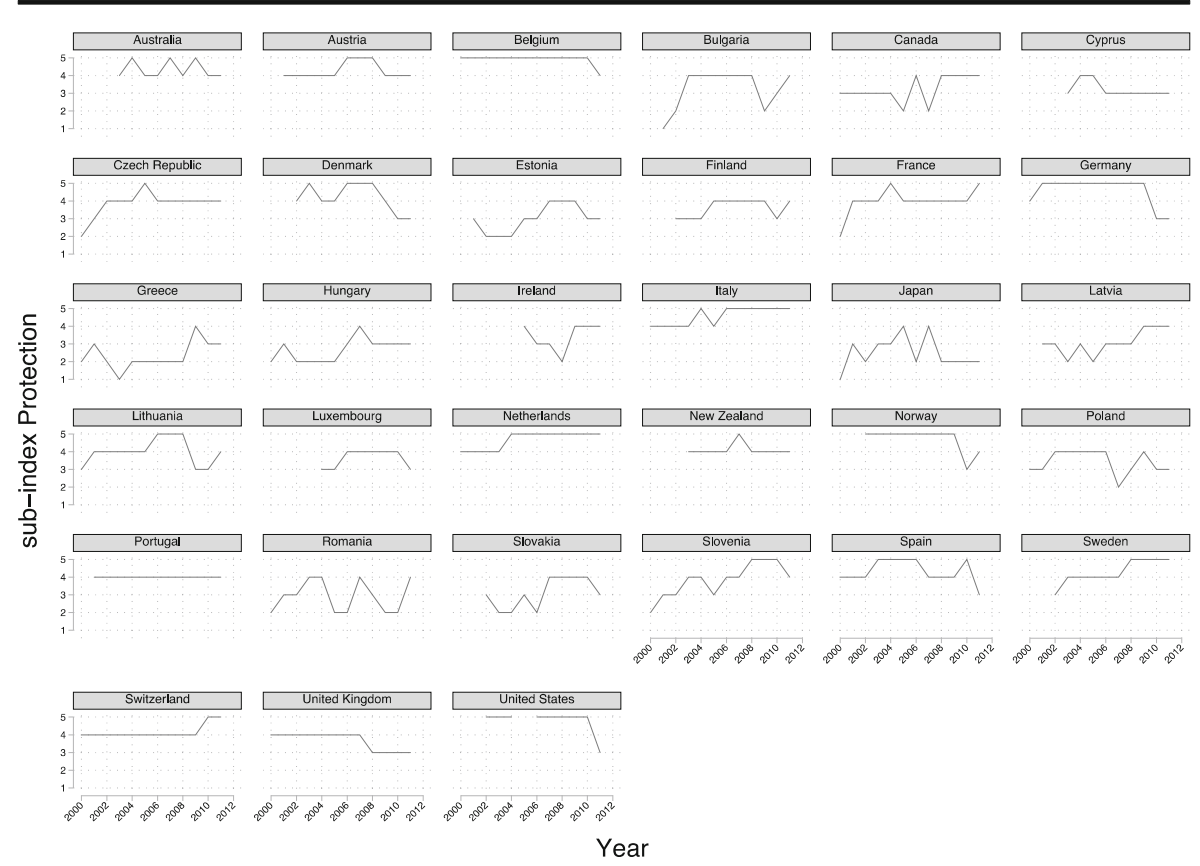

Fig. 4 Trajectories of victim protection in all countries of the sample

Open Access This article is distributed under the terms of the Creative Commons Attribution 4.0 International License (http://creativecommons.org/licenses/by/4.0/), which permits unrestricted use, distribution, and reproduction in any medium, provided you give appropriate credit to the original author(s) and the source, provide a link to the Creative Commons license, and indicate if changes were made.

\section{References}

1. Belser, P. (2005). Forced labour and human trafficking: estimating the profits. Special action programme to combat forced labour. Geneva: International Labour Office.

2. Brysk, A. (2011). Rethinking trafficking: human rights and private wrongs. In A. Brysk \& A. ChoiFitzpatrick (Eds.), Human trafficking and human rights: rethinking contemporary slavery (pp. 74-85). Philadelphia: University of Pennsylvania Press.

3. Kutnick, B., Belser, P., \& Danailova-Trainor, G. (2007). Methodologies for global and national estimation of human trafficking victims: current and future approaches. Geneva: International Labour Office.

4. United Nations (2000). Protocol to prevent, suppress and punish trafficking in persons, especially women and children, Supplementing the United Nations Convention Agains Transnational Organized Crime.

5. UNODC (2006). Trafficking in persons: global patterns. Vienna: United Nations Office on Drugs and Crime.

6. Human Smuggling and Trafficking Center (2008). Domestic human trafficking - an internal issue. Retreived June 7, 2016 from http://www.state.gov/documents/organization/113612.pdf

7. UNODC (2009). Global report on trafficking in persons. Vienna: United Nations Office on Drugs and Crime. 
8. Cho, S.-Y., Dreher, A., \& Neumayer, E. (2014). The determinants of anti-trafficking policies - evidence from a new index. Scandinavian Journal of Economics, 116(2), 429-454.

9. Cho, S.-Y., \& Vadlamannati, K. C. (2012). Compliance with the anti-trafficking protocol. European Journal of Political Economy, 28(2), 249-265.

10. Charnysh, V., Lloyd, P., \& Simmons, B. (2015). Frames and consensus formation in international relations: The case of trafficking in persons. European Journal of International Relations, 21(2), 323351.

11. Akee, R., Bedi A., Basu A. K., \& Chau, N. H. (2010). Transnational trafficking, law enforcement and victim protection: a middleman's perspective. IAZ Discussion Paper No. 6226. Available at SSRN: http://ssrn.com/abstract=1977812.

12. Avdeyeva, O. A. (2012). Does reputation matter for states' compliance with international treaties? States enforcement of anti-trafficking norms. The International Journal of Human Rights, 16(2), 289-320.

13. Simmons, B. A., \& Lloyd, P. (2010). Intersubjective frames and rational choice: transnational crime and the case of human trafficking. In Hauser Globalization Colloquium Fall 2010. New York: University.

14. Bartilow, H. A. (2008). Gender representation and the sex trade: domestic sources of international compliance against human trafficking. Paper presented at the 49th International Studies Association Annual Convention, San Francisco, CA, March 26. http://citation.allacademic.com//meta/p_mla apa research citation/2/5/1/6/3/pages251635/p251635-1.php. Accessed 14 April 2015.

15. Wooditch, A. (2012). Human trafficking law and social structures. International Journal of Offender Therapy and Comparative Criminology, 56(5), 673-690.

16. Potrafke, N. (2012). Policies against human trafficking: the role of religion and political institutions. CESifo Working Paper Series No. 4278. Available at SSRN: http://ssrn.com/abstract=2284736. Accessed 14 April 2015.

17. Andrijasevic, R. (2007). Beautiful dead bodies: gender, migration and representation in anti-trafficking campaigns. Feminist Review, 86, 24-44.

18. Watson, J., \& Silkstone, C. (2006). Human trafficking as a form of gender-based violence - protecting the victim. Agenda: Empowering Women for Gender Equity, 70, 110-118.

19. Jeffreys, S. (2009). Prostitution, trafficking and feminism: an update on the debate. Women's Studies International Forum, 32(4), 316-320.

20. Spanger, M. (2011). Human trafficking as a lever for feminist voices? Transformations on the Danish policy field of prostitution. Critical Social Policy, 31(4), 517-539.

21. Council of Europe (2005). The convention of action against trafficking in human beings (p. 197). Warsaw: Council of Europe Treaty Series No.

22. Gozdziak, E. M., \& Collett, E. A. (2005). Research on human trafficking in North America: a review of literature. International Migration, 43(1/2), 99-128.

23. Goodey, J. (2008). Human trafficking: sketchy data and policy responses. Criminology and Criminal Justice, 8(4), 421-442.

24. Kangaspunta, K. (2003). Mapping the inhuman trade: preliminary findings of the database on trafficking in human beings. In J. van Dijk \& V. Ruggiero (Eds.), United Nations Forum on Crime and Society (pp. 81-104). Vienna: United Nations Office on Drugs and Crime.

25. Scarpa, S. (2008). Trafficking victim's protection in international human rights, criminal and labour Law. In S. Scarpa (Ed.), Trafficking in human beings: modern slavery (pp. 84-137). Oxford: Oxford University Press.

26. Touzenis, K. (2010). Trafficking in human beings. Human rights and trans-national criminal law. Developments in law and practices. Paris: UNESCO.

27. Das, J., DiRienzo, C. E., Lanier Jr., D., \& Coleman, R. (2013). Anti-human trafficking policies and freedom of the press: a cross-country study. International Journal of Management \& Marketing Research, 6(2), 1-10.

28. Simeunovic-Patic, B., \& Copic, S. (2010). Protection and assistance to victims of human trafficking in Serbia: recent developments. European Journal of Criminology, 7(1), 45-60.

29. Smith-Cannoy, H. M., \& Smith, C. A. (2012). Human trafficking and international cheap talk: the dutch government and the island territories. Journal of Human Rights, 11(1), 51-65.

30. van Dijk, J., \& Klerx-van Mierlo, F. (2011). Indicators of corruption: further explorations of the link between corruption and implementation failure in anti-trafficking policies. International Victimology Institute (INTERVICT): University of Tilburg.

31. US Department of State (2002). Victims of trafficking and violence protection act 2000. Trafficking in persons report June 2002. Washington, D.C.: United States of America Department of State. http://www. state.gov/j/tip/rls/tiprpt/2002/index.htm. Accessed 14 April 2015. 
32. Gilpin, R. (2001). Global political economy: understanding the international economic order. Princeton: Princeton University Press.

33. Joseph, J. (2002). Hegemony: a realist analysis. Oxon, NY: Routlege.

34. Waltz, K., \& Art, R. (1983). The use of force: military power and international politics. New York. NY: University Press of America.

35. Dancy, G., \& Sikkink, K. (2012). Ratification and human rights prosecutions: toward a transnational theory of treaty compliance. New York University Journal of International Law and Politics, 44(2), 751790.

36. Hathaway, O. A. (2007). Why do countries commit to human rights treaties? Journal of Conflict Resolution, 51(4), 588-621.

37. Moravcsik, A. (2000). The origins of human rights regimes: democratic delegation in postwar Europe. International Organization, 54(2), 217-252.

38. Simmons, B. A., \& Danner, A. (2010). Credible commitments and the international criminal court. International Organization, 64(1), 225-256.

39. Perrin, B. (2010). Just passing through? International legal obligations and policies of transit countries in combating trafficking in persons. European Journal of Criminology, 7(1), 11-27.

40. Chuang, J. (2006). The United States as global sheriff: using unilateral sanctions to combat human trafficking. Michigan Journal of International Law, 27(2), 437-494.

41. Kelley, J. G., \& Simmons, B. A. (2014). Politics by number: indicators as social pressure in international relations. American Journal of Political Science. doi:10.1111/ajps.12119.

42. Simmons, B. A. (2000). International law and state behavior: commitment and compliance in international monetary affairs. American Political Science Review, 94(4), 819-835.

43. Pitkin, H. (1967). The concept of representation. Berkeley, CA: University of California Press.

44. Banducci, S. A., Donovan, T., \& Karp, J. A. (2004). Minority representation, empowerment, and participation. The Journal of Politics, 66(2), 534-556.

45. Esman, M. J. (1999). Public administration and conflict management in plural societies: the case for representative bureaucracy. Public Administration and Development, 19, 353-366.

46. Meier, K. J. (1993). Representative bureaucracy: a theoretical and empirical exposition. In J. L. Perry (Ed.), Research in public administration (pp. 1-35). Greenwich, CT: JAI.

47. Merry, S. E. (2006). Human rights \& gender violence. translating international law into local justice. Chicago: The University of Chicago Press.

48. Pollak, J., Bátora, J., Mokre, M., Sigalas, E., \& Slominski, P. (2009). On political representation. Myths and challenges. RECON Online Working Paper 2009/03, ARENA Centre for European Studies, Univeristy of Oslo. https://ideas.repec.org/p/erp/reconx/p0042.html. Accessed 14 April 2015.

49. Chattopadhyay, R., \& Duflo, E. (2004). Women as policy makers: evidence from a randomized policy experiment in India. Econometrica, 72(5), 1409-1443.

50. Keiser, L. R., Wilkins, V. M., Meier, K. J., \& Holland, C. A. (2002). Lipstick and logarithms: gender, institutional context, and representative bureaucracy. The American Political Science Review, 96(3), 553-564.

51. Meier, K. J., \& Nicholson-Crotty, J. (2006). Representative bureaucracy and law enforcement: the case of sexual assault. Public Administration Review, 66(6), 850-860.

52. Sawer, M. (2000). Parliamentary representation of women: from discourse of justice to stragegies of accountability. International Political Science Review, 21(4), 361-380.

53. Thomas, S. (1991). The impact of women on state legislative policies. The Journal of Politics, 53(3), 958-976.

54. Wilkins, V. M. (2004). Linking passive and active representation by gender: the case of child support agencies. Journal of Public Administration Research and Theory, 16(1), 87-102.

55. Alvarez, M. B., \& Alessi, E. J. (2012). Human trafficking is more than sex trafficking and prostitution: implications for social work. Affilia: Journal of Women and Social Work, 27(2), 142-152.

56. Hibbs, D. A. (1986). Political parties and macroeconomic policies and outcomes in the United States. The American Economic Review, 76(2), 66-70.

57. Schmidt, M. G. (1996). When parties matter: a review of the possibilities and limits of partisan influence on public policy. European Journal of Political Research, 30, 155-183.

58. Alesina, A., \& Rosenthal, H. (1995). Partisan politics, divided government and the economy. Cambridge, MA: Cambridge University Press.

59. Huber, E., \& Stephens, J. D. (1993). Political parties and public pensions: a quantitative analysis. Acta Sociologica, 36(4), 309-325.

60. Hibbs, D. A. (1977). Political parties and macroeconomic policy. The American Political Science Review, 71(4), 1467-1487. 
61. Alvarez, R. M., Garrett, G., \& Lange, P. (1991). Government partisanship, labor organization, and macroeconomic performance. The American Political Science Review, 85(2), 539-556.

62. Budge, I., Klingemann, H. D., Volkens, A., Bara, J., \& Tanenbaum, E. (2001). Mapping policy preferences. Estimates for parties, electors, and governments 1945-1998. Oxford: Oxford University Press.

63. Hicks, A. M., \& Swank, D. H. (1992). Politics, institutions, and welfare spending in industrialized democracies, 1960-82. The American Political Science Review, 86(3), 658-674.

64. Strøm, K. (1990). A behavioral theory of competitive political parties. American Journal of Political Science, 34(2), 565-589.

65. Budge, I., \& Hofferbert, R. I. (1990). Mandates and policy outputs: U.S. party platforms and federal expenditures. The American Political Science Review, 84(1), 111-131.

66. King, G., \& Laver, M. (1993). On party platforms, mandates, and government spending. The American Political Science Review, 87(3), 744-750.

67. van Dijk, J., \& Klerx-van Mierlo, F. (2014). Quantitative indices for anti-human trafficking policies: based on reports of the U.S. State Department and the Council of Europe. Crime, Law and Social Change, 61(2), 229-250.

68. Wooditch, A. (2011). The efficacy of the trafficking in persons report: a review of the evidence. Criminal Justice Policy Review, 22(4), 471-493.

69. Frank, R. W. (2013b) Human trafficking indicators, 2000-2011 data codebook (Version 2013.1). Sydney: University of Sydney. Available from SSRN and http://human-trafficking-indicators.org. Accessed 14 April 2015.

70. Armingeon, K., Careja, R., Weisstanner, D., \& Engler, S. (2012). Comparative political data set III 1990-2010. Institute of Political Science: University of Berne.

71. Armingeon, K., Careja, R., Weisstanner, D., \& Engler, S. (2010). Codebook: Comparative Political Data Set III, 1990-2010. Institute of Political Science: University of Berne.

72. Klingemann, H. D., Volkens, A., Bara, J., Budge, I., \& McDonald, M. (2006). Mapping policy preferences II. In Estimates for parties, electors, and governments in Eastern Europe, the European Union and the OECD, 1990-2003. Oxford: Oxford University Press.

73. Volkens, A., Lehmann, P., Merz, N., Regel, S., Werner, A., Lavewell, O. P., \& Schulte, H. (2013). The manifesto data collection. Manifesto Project (MRG/CMP/MARPOR). Version 2013 b. Wissenschaftszentrum Berlin für Sozialforschung (WZB).

74. Howard, N., \& Lalani, M. (2008). Editorial introduction: the politics of human trafficking. STAIR, 4(1), 5-15.

75. Surtees, R. (2008). Traffickers and trafficking in southern and Eastern Europe: considering the other side of human trafficking. European Journal of Criminology, 5(1), 39-68.

76. Best, J. (1999). Random violence: how we talk about new crimes and new victims. Berkeley and Los Angeles, CA: University of California Press.

77. Henisz, W. J. (2000). The institutional environment for economic growth. Economics and Politics, 12(1), 1-31.

78. Henisz, W. J., \& Zelner, B. A. (2010). Measures of political risk database. The McDonough School of Business: Georgetown University.

79. Zhang, S. X., \& Pineda, S. L. (2008). Corruption as a Causal Factor in Human Trafficking. In D. Sigel \& H. Nelen (Eds.), Organized crime: culture, markets and policies. New York: Springer, pp. 41-55.

80. La Porta, R., Lopez-de Silanes, F., \& Shleifer, A. (2008). The economic consequences of legal origins. Journal of Economic Literature, 46(2), 285-332.

81. Beck, N. (2001). Time-series-cross-section data: what have we learned in the past few years? Annual Review of Political Science, 4, 271-293.

82. Beck, N., \& Katz, J. N. (2011). Modeling dynamics in time-series-cross-section political economy data. Annual Review of Political Science, 14, 331-352.

83. Teorell, J., Samanni, M., Holmberg, S., \& Rothstein, B. (2012). The quality of government basic dataset version 21 May 2012. The Quality of Government Institute: University of Gothenburg.

84. Frank, R. W. (2013a). Human trafficking indicators, 2000-2011: a new dataset. Sydney: University of Sydney. Available from SSRN and http://human-trafficking-indicators.org. Accessed 14 April 2015.

85. Rohrlack, C. (2007). Logistische und ordinale regression. In S. Albers (Ed.), Methodik der empirischen Sozialforschung (pp. 199-214). Wiesbaden: Gabler.

86. Kittel, B. (1999). Sense and sensitivity in pooled analysis of political data. European Journal of Political Research, 35(2), 225-253.

87. Plümper, T., Troeger, V. E., \& Manow, P. (2005). Panel data analysis in comparative politics: linking method to theory. European Journal of Political Research, 44(2), 327-354. 
88. Lancaster, T. (2000). The incidental parameter problem since 1948. Journal of Econometrics, 95, 391-413.

89. Nickell, S. (1981). Biases in dynamic models with fixed effects. Econometrica, 49(6), 1417-1426.

90. US Department of State (2007). Trafficking in persons report June 2007. June, Washington, D.C.: United States of America Department of State. http://www.state.gov/j/tip/rls/tiprpt/2007/index.htm. Accessed 14 April 2014.

91. US Department of State (2008). Trafficking in persons report June 2008. Washington, D.C.: United States of America Department of State. http://www.state.gov/j/tip/rls/tiprpt/2008/index.htm. Accessed 14 April 2014.

92. US Department of State (2010). Trafficking in persons report 10th Edition. Washington, D.C.: United States of America Department of State. http://www.state.gov/j/tip/rls/tiprpt/2010/index.htm. Accessed 14 April 2015.

93. US Department of State (2001). Victims of trafficking and violence protection Act of 2000a. Trafficking in Persons Report. Washington, D.C.: United States of America Department of State. http://www.state. gov/j/tip/rls/tiprpt/2001/index.htm. Accessed 14 April 2015.

94. US Department of State (2003). Trafficking in Persons Report June 2003. Washington, D.C.: United States of America Department of State. http://www.state.gov/j/tip/rls/tiprpt/2003/index.htm. Accessed 14 April 2015.

95. GRETA (2014). Group of experts on action against trafficking in human beings report concerning the implementation of the council of Europe convention on action against trafficking in human beings by Slovenia first evaluation round. Strasbourg: Council of Europe.

96. US Department of State (2005). Trafficking in persons report June 2005. Washington, D.C.: United States of America Department of State. http://www.state.gov/j/tip/rls/tiprpt/2005/index.htm. Accessed 14 April 2015.

97. US Department of State (2009). Trafficking in persons report june 2009. Washington, D.C.: United States of America Department of State. http://www.state.gov/j/tip/rls/tiprpt/2009/index.htm. Accessed 14 April 2015.

98. GRETA (2011). Group of experts on action against trafficking in human beings report concerning the implementation of the council of Europe convention on action against trafficking in human beings by Bulgaria first evaluation round. Strasbourg: Council of Europe.

99. US Department of State (2006). Trafficking in persons report June 2006. June, Washington, D.C.: United States of America Department of State. http:/www.state.gov/j/tip/rls/tiprpt/2006/index.htm. Accessed 14 April 2015.

100. GRETA (2012). Group of experts on action against trafficking in human beings report concerning the implementation of the council of Europe convention on action against trafficking in human beings by the United Kingdom first evaluation round. Strasbourg: Council of Europe.

101. Halliday, T. C. (2009). Recursivity of global normmaking: a sociolegal agenda. Annual Review of Law and Social Science, 5(1), 263-289.

102. Merry, S. E. (2011). Indicators, human rights, and global governance: with CA comment by John M. Conley. Current Anthropology, 52 Supplement 3, S83-S95.

103. Thijssen, P. (2012). From mechanical to organic solidarity, and back: with Honneth beyond Durkheim. European Journal of Social Theory, 15(4), 454-470. 